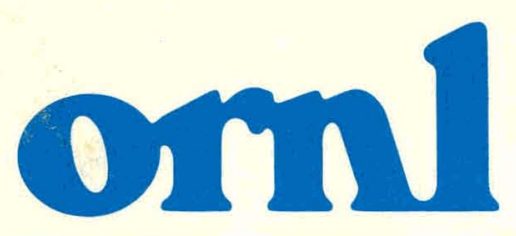

OAK RIDGE NATIONAL LABORATORY

\section{ORNL/TM-7155}

\title{
Fifth Personnel Dosimetry Intercomparison Study
}

\author{
C. S. Sims
}

OPERATED BY

UNION CARBIDE CORPORATION FOR THE UNITED STATES DEPARTMENT OF ENERGY 


\section{DISCLAIMER}

This report was prepared as an account of work sponsored by an agency of the United States Government. Neither the United States Government nor any agency Thereof, nor any of their employees, makes any warranty, express or implied, or assumes any legal liability or responsibility for the accuracy, completeness, or usefulness of any information, apparatus, product, or process disclosed, or represents that its use would not infringe privately owned rights. Reference herein to any specific commercial product, process, or service by trade name, trademark, manufacturer, or otherwise does not necessarily constitute or imply its endorsement, recommendation, or favoring by the United States Government or any agency thereof. The views and opinions of authors expressed herein do not necessarily state or reflect those of the United States Government or any agency thereof. 


\section{DISCLAIMER}

Portions of this document may be illegible in electronic image products. Images are produced from the best available original document. 


\section{Printed in the United States of America. Available from National Technical Information Service U.S. Department of Commerce 5285 Port Royal Road, Springfield, Virginia 22161 NTIS price codes-Printed Copy: A05; Microfiche A01}

This report was prepared as an account of work sponsored by an agency of the United States Government. Neither the United States Government nor any agency thereof, nor any of their employees, makes any warranty, express or implied, or assumes any legal liability or responsibility for the accuracy, completeness, or usefulness of any information, apparatus, product, or process disclosed, or represents that its use would not infringe privately owned rights. Reference herein to any specific commercial product, process, or service by trade name, trademark, manufacturer, or otherwise, does not necessarily constitute or imply its endorsement, recommendation, or favoring by the United States Government or any agency thereof. The views and opinions of authors expressed herein do not necessarily state or reflect those of the United States Government or any agency thereof. 
ORNL/TM-7. 155

Contract No. W-7405-eng-26

Health and Safety Research Division

FIFTH PERSONNEL DOSIMETRY INTERCOMPARISON STUDY

C. S. Sims

Date Published: February 1980

NOTICE This document contains information of a preliminary nature. It is subject to revision or correction and therefore does not represent a final report.

DAK. RIDGE NATIONAI I.ABORATORY

Oak Ridge, Tennessee 37830

operated by

UNION CARBIDE CORPORATION

for the

DEPARTMENT OF ENERGY 


\section{THIS PAGE}

WAS INTENTIONALLY

LEFT BLANK 


\section{CONTENTS}

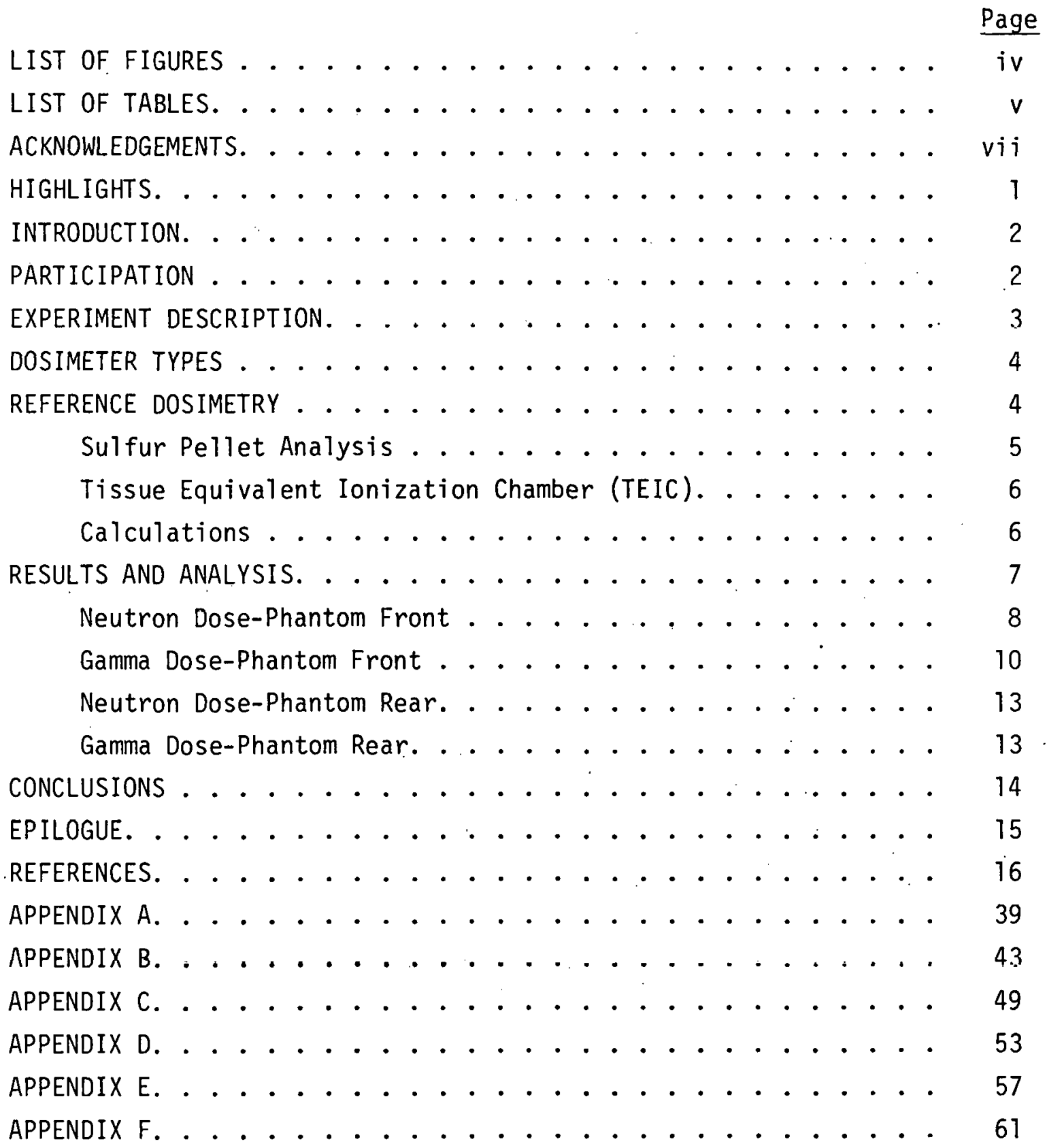




\section{LIST OF FIGURES}

Page

1 Lucite shield................. 18

2 Concrete shield...................... 19

3 Experimental arrangement for PDIS exposures ...... 20 


\section{LIST OF TABLES}

Page

1 Summary of experimental conditions ........... 21

2 Dosimeters as described by the participants ....... 22

3 Reference gamma dose equivalent ........... 23

4 Neutron dose equivalent from sulfur pellet analysis . . . . 24

5 Neutron dose equivalent from tissue equivalent ionization chamber measurements ............... 24

6 Neutron dose equivalent from calculations ....... 25

7 Reference neutron dose equivalent ......... 26

8 Tabulation of reported results - PDIS 5, run 1, unshielded . 27

9 Tabulation of reported results - PDIS 5, run 2, unshielded . 28

10 Tabulation of reported results - PDIS 5, run 3, Lucite shield ..................... 29

11 Tabulation of reported results - PDIS 5, run 4, Lucite

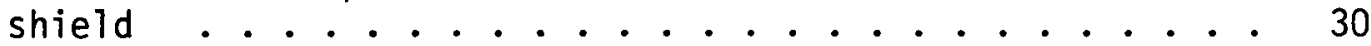

12 Tabulation of reported results - PDIS 5, run 5, concrete

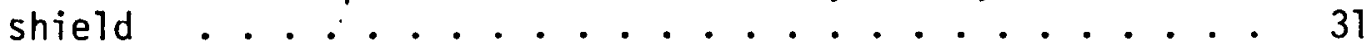

13 Tabulation of reported results - PDIS 5, run 6 , concrete

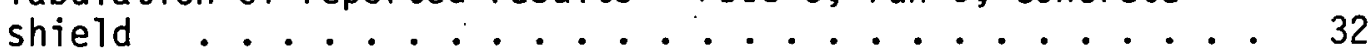

14 Analysis of neutron dose equivalent results on front of phantoms .................... 33

15 Neutron dose equivalent on front of phantoms by type of dosimeter.................. 34

16 Analysis of gamma dose equivalent results on front of phantoms ................... 35

17 Gamma dose equivalent on front of phantoms by type of dosimeter ................ 36

18 Analys is of neutron dose equivalent results on rear of phantoms ................... 37

19 Analysis of gamma dose equivalent results on rear of phantoms 


\section{THIS PAGE}

\section{WAS INTENTIONALLY \\ LEFT BLANK}




\section{ACKNOWLEDGMENTS}

The intercomparison study was conducted in an orderly fashion and without problem due to the commendable efforts of $M$. R. Davis in handling the return of the dosimeters to the participants, H. W. Dickson in providing overall guidance to the study, L. W. Gilley in reactor operation and experimental setup, and G. R. Patterson in dosimeter preparation and evaluation. 


\section{FIFTH PERSONNEL DOSIMETRY INTERCOMPARISON STUDY}

C. S. Sims

\section{HIGHLIGHTS}

The fifth in the continuing series of Personnel Dosimetry Intercomparison Studies was held March 20-22, 1979, at the 0ak Ridge National Laboratory. The Health Physics Research Reactor (HPRR) served as the source of low-level radiation doses (1-15 $\mathrm{mSv}^{*}$ neutron, $0.1-1 \mathrm{mSv}$ gamma) during six different runs using shields to provide three different neutron and gamma spectra. Participants from 29 organizations, the most in the history of the studies, exposed various types of personnel dosimeters mounted on phantoms. Typical reported dose equivalents varied by factors of 2 to 3 for neutrons and 3 to 4 for gamma-rays. Although thermoluminescent (TLD) albedo dosimeters were the most popular, track dosimeters generally provided the most accurate measurements of neutron dose equivalent. The gamma dose equivalent was most accurately measured by TLDs; however, one particular type (TLD-100) was found to be unsatisfactory (results much too high) for measurement of HPRR gamma-rays. Film was found to be unsatisfactory (results much too low) for the measurement of HPRR neutrons. It appears that more accurate measurements could be made if some participants would select dosimeters better suited to measure the various types of radiation and others would give greater attention to the response characteristics of their dosimeters and make corrections based on those characteristics and a knowledge of the spectrum being measured. Even though improved dose estimates can be made by more suitable dosimeter selection and better analysis techniques, the study

\footnotetext{
${ }^{\star} 1 \mathrm{mSv}=100 \mathrm{mrem}$.
} 
results are a strong indication that more research and development work is needed in mixed field radiation dosimetry.

\section{INTRODUCTION}

The fifth Personnel Dosimetry Intercomparison Study (PDIS) was conducted at the Oak Ridge National Laboratory's (ORNL) Dosimetry Applications Research (DOSAR) facility on March 20-22, 1979. This study is the latest PDIS in the continuing series ${ }^{1-4}$ started at the DOSAR facility in 1974. The PDIS is a three day study, typically in March, where personnel dosimeters are mailed to the DOSAR facility, exposed to a range of lowleve ${ }^{\star}$ neutron radiation doses (1-15 mSv or equivalently, 100-1500 mrem $)^{\dagger}$ and neutron-to-gamma ratios $(1: 1-10: 1$ ) using the Health Physics Research Reactor (HPRR) ${ }^{5}$ as the radiation source, and returned to the participants for evaluation. This report is a summary and analysis of the results reported by the various participants. The participants are able to "intercompare" their results with those of others who made dose measurements under identical experimental conditions.

\section{PARTICIPATION}

Twenty-nine organizations, the most in POIS history, participated in the March, 1979, study. Twenty-two organizations were from the United States, six were from Europe, and one was from Canada. These organizations include dosimeter vendors, national laboratories, the

\footnotetext{
* The DOSAR staff also conducts an annual Nuclear Accident Dosimetry (NAD) 6 intercomparison study in August. Typical neutron doses in the NAD studies are in the range 0.25-8 Gy (25-800 rad).

tRadiation dose and dose equivalent are presented in this report in the international system of units. Conversions to the more traditional units in which the results were originally reported to the DOSAR staff are also shown.
} 
military, universities, and utilities. A complete list of study participants and the abbreviations by which they are identified throughout the report are given in Appendix $A$.

Participation has been unlimited and available to any organizátion legitimately interested in personnel dosimetry and willing to cooperate with the DOSAR staff. The participant pays dosimeter shipping costs and agrees to expeditiously furnish measurement results to share with the other participants. Additional details relative to participation are found in Appendix B which is the letter announcing the fifth PDIS study.

\section{EXPERIMENT DESCRIPTION}

The HPRR is a small, unmoderated, fast pulse reactor. Operating in the steady state mode, the HPRR served as the radiation source for the six different exposures made during the fifth PDIS. Various dose equivalents and neutron-to-gamma ratios likely to be encountered in personnel dosimetry were produced by controlling the reactor power level and run duration and by utilizing three different shielding conditions: unshielded, a 12-cm-thick Lucite shield, and a $20-\mathrm{cm}-$ thick concrete shield. Physical details of the shields are shown in Figs. 1 and 2. The two-dimensional discrete ordinates transport (DOT) code calculated neutron spectra ${ }^{6,7}$ for the various shielded conditions are presented in Appendices $C$ and $D$.

Dosimeters were generally mounted on the front surfaces (i.e., the surfaces facing the HPRR and $3 \mathrm{~m}$ from it) of trunk sections of waterfilled Bomab ${ }^{8}$ phantoms. The Bomab trunk section has an elliptical cross 
section with dimensions $20 \mathrm{~cm} \times 30 \mathrm{~cm}$ and is $40 \mathrm{~cm}$ high. Some participants chose to have their dosimeters mounted on the rear of the Bomab.

Figure 3 is a schematic which shows the positioning of the phantoms, the shields, and the HPRR for all six exposures made during the fifth PDIS. Table 1 is a summary of the experimental conditions. It should be noted from Table 1 that the actual neutron dose equivalents for a particular shielding configuration should be in the same ratio as the number of fissions (e.g., the dose equivalent from exposure number 2 should be eight times larger than that from exposure number 1). The gamma dose is not in this ratio due to the significant contribution of residual gamma rays from fission products at these low power levels.

\section{DOSIMETER TYPES}

The types of dosimeters used in the fifth PDIS are summarized in Table 2. The descriptions given in the table were furnished by the participants who returned the Data Report Sheet (see Appendix E). Basically, participants used two types of dosimeters, film and thermoluminescent dosimeters (TLD), for gamma dose measurements. The dosimeter types used for neutron measurements included TLD, TLD-albedo, film, and track-etch. In the remainder of this report, the dosimeters are referred to as film, TLD (for TLD and TLD-albedo), and track (for track-etch). Descriptions of these dosimeter types are readily available in the 1 i terature. 9,10

\section{REFERENCE DOSIMETRY}

The gamma dose and the neutron dose were measured and calculated by DOSAR personnel for each of the runs during the PDIS in order to provide 
reference dosimetry. The results presented below are the staff's best estimates of the actual dose equivalent.

The gamma dose on the front of the phantoms was measured by Harshaw TLD-700 ${ }^{7}$ LiF chips calibrated using ${ }^{226} \mathrm{Ra}$ and by a small Geiger-Mueller (G-M) tube ${ }^{11}$ with a lithium shield, calibrated using ${ }^{60} \mathrm{Co}$. In addition, the gamma dose at an air station was measured with another G-M tube and converted to dose to the phantom by using ratios of phantom dose to dose in air developed through the years at the DOSAR facility. The dose at the rear of the phantom was also measured by TLD's. All of these results are reported in Table 3.

The DOSAR staff used three different methods to determine the neutron dose equivalent for the PDIS exposures. These methods are discussed below.

\section{Sulfur Pellet Analysis}

The foundation of routine neutron dosimetry at the HPRR is a standard sized $(22 \mathrm{~g})$ sulfur pellet ${ }^{12}$ located at a fixed position near the reactor core. The induced ${ }^{32} \mathrm{p}$ beta activity of the pellet is measured after an operation and can be related to the unshielded tissue kerma at an area monitoring station at any distance from the HPRR via an accurately known neutron dose vs. distance relationship developed at the DOSAR facility over 16 years. of operational experience. To obtain the dose equivalent on the front of a phantom, the unshielded dose is modified by an experimentally determined shield dose attenuation factor, ${ }^{13}$ a factor to convert from area monitor dose to phantom dose, ${ }^{13}$ and an effective quality factor ${ }^{14,15}$ (QF) for each spectrum. The $Q F$ used for the bare 
and the Lucite shielded HPRR spectra are well supported numbers. $3,14,15$ Specifically, they are effective QF associated with element 57 (a surface element) of the Auxier phantom. ${ }^{16}$ The QF for the concrete shielded HPRR is much less certain; the value* used is the average of measurements ${ }^{15}$ (11.7) and calculations ${ }^{17}$ based on a Monte Carlo determined spectrum (7.9). The dose at the rear of the phantom is estimated by applying a front-to-rear conversion factor developed from previous PDIS results. The dose equivalents determined by this method are presented in Table 4.

Tissue Equivalent Ionization Chamber (TEIC)

The DOSAR facility has recently installed a TEIC to do on-line measurements. The sensor, designated RD-1 by the manufacturer, ${ }^{\dagger}$ is a 7.3-cm-diam. spherical ionization chamber filled with tissue equivalent gas and having $0.16-\mathrm{cm}$-thick walls made of Shonka A-150 plastic. ${ }^{19}$ The TEIC was calibrated by the vendor using ${ }^{137} \mathrm{Cs}$ and checked hy the DOSAR staff using ${ }^{60}$ Co. This TEIC was used to measure the total (i.e., neutron and gamma) dose at a monitoring station in air. The neutron dose was obtained by subtracting the gamma dose as determined by the previously mentioned G-M tube. The conversion from dose in air to dose equivalent. on the phantom is the same as for the sulfur pellet analysis. The results are presented in Table 5 .

\section{Calculations}

The energy expended (i.e., power level $\times$ time of operation) during each run was determined from HPRR instrumentation. By knowing the energy release per fission, the number of fissions during each run was

*The value used is 9.8. It should be noted that it is standard practice 18 to use $Q F=10$ for cases where the neutron spectrum is completely unknown.

†Digital Data Dosimetry (Tulsa, Oklahoma). 
calculated. The neutron fluence at the location of interest $(3 \mathrm{~m}$ from HPRR) was computed from the number of fissions and the fluence per $10^{17}$ fissions from the DOT code calculated spectra (see Appendices $C$ and D). Dose conversion factors, rads per unit fluence, " have been determined by multiplying the fluence in each energy interval of the spectra by the element 57 dose per unit fluence in that interval as tabulated ${ }^{16}$ and summing over all intervals. The calculated fluences were multiplied by these conversion factors to give the dose for each PDIS run. The conversion to dose equivalent on the front and on the rear of the phantoms was performed using the techniques described above. These calculated data are presented in Table 6.

The reference neutron dose equivalent for each run is shown in Table 7. The reference value is taken to be the average value determined from the sulfur pellet analysis and the TEIC measurements. The calculational method determined values are not included because they are traditionally not used ${ }^{4}$ and because there are unresolved anomalies 4,20 between the DOT code calculated spectra and measurements made for steel and concrete shields at the DOSAR facility.

\section{RESULTS AND ANALYSIS}

The PDIS participants reported their results on sheets provided by the DOSAR staff (see Appendix E). Tables 8-13 contain the reported dose equivalent values and Appendix $F$ is a compilation of the participants' dosimetry related comments included on the data report sheets. The DOSAR reference values are also included in the tables for ease of comparison, but are not included in any of the subsequent data manipulation

\footnotetext{
*Equivalent international units are shown in Table 6.
} 
(e.g., mean reported values). Six phantoms equidistant from the HPRR were required to accommodate the dosimeters exposed during each run. Dose results have not been reported by phantom since dose variation among dosimeters on the various phantoms has been shown to be insignificant. 4

\section{Neutron Dose-Phantom Front}

Neutron dose equivalent results from measurements made on the front of phantoms are summarized in Table 14. When all of the reported results are considered, the mean values of the dose equivalent are significantly higher (an average of about $40 \%$ for the unshielded runs, about $300 \%$ for the Lucite shielded runs, and about $250 \%$ for the concrete shielded runs) than the reference values and the standard deviations range from 108 to $201 \%$. The median ${ }^{\star}$ values are, however, only $6-43 \%$ higher than the reference values for the six runs. That the participants in general had difficulty in making neutron dose measurements is further evidenced by the fact that the reported results for run 3 range from 0-155.8 mSv (0$15,580 \mathrm{mrem})$ and for run 5 range from $0.27-166.9 \mathrm{mSv}(27-16,690 \mathrm{mrem})$.

In order that the statistical analysis of the data reported might be more representative of the ability of participants to quantify neutron dose, the data have been reanalyzed with two sets of results excluded. The RPB results were excluded because no attempt was made to correct for gross spectral differences between the calibration source used and the actual measurements made. The UTAH results were excluded because their method is actually only a screening method and not intended to measure dose accurately. This reanalysis is reported in Table 14 under the

* Median values as well as mean values and standard deviations are reported so that the reader may more easily understand the variation among reported dose results. 
column "Subset of reported results." These data have mean values which are higher than the reference values by an average of about $10 \%$ for the unshielded runs, 35\% for the Lucite shielded runs, and $40 \%$ for the concrete shielded runs. The standard deviations are $46-100 \%$ of the means (the unshielded runs have lower standard deviations than the shielded runs) and the median values differ from the reference values by $1-18 \%$. For measurements of neutron dose equivalent performed by several groups in the range $1-15 \mathrm{mSV}(100-1500 \mathrm{mrem})$, these data indicate that:

(a) it is not unusual for results to differ by a factor of 2 to 3 ,

(b) unshielded doses are more accurately measured than shielded doses,

(c) the majority of the reported doses are higher than the reference dose.

A summary of the neutron dose equivalent as measured by three different types of dosimeters is presented in Table 15. The data show that film users report dose equivalents which are much lower than the actual dose in every case; in fact, only in the case of run 4 is the mean value within two standard deviations of the reference value. The mean values are less than $40 \%$ of the reference values for all cases. These low results are explained by the fact that film generally fails to respond to neutrons with energies below about $0.5 \mathrm{MeV}$ (refs. 10 and 18) and has relatively low response to neutrons with energies up to about $1.2 \mathrm{MeV} .^{10}$ This energy response also explains why the film results were slightly better for the unshielded runs than for the shielded runs. In addition, film can have a fading problem resulting in low dose values if it is not carefully packaged and read promptly after exposure to radiation. 
In general, track dosimeters yielded results closer to the reference values than did the other type dosimeters. The median values were within $17 \%$ of the reference values for all cases. Except for run 1 where a single reported result was exceptionally high, the mean values for track results were within 15\% of the reference values and the standard deviations were less than for the other type dosimeters. It should, however, be pointed out that no individual track dosimeter user reported results within $23 \%$ of the reference values for all runs.

The neutron dose equivalent results reported by TLD (primarily TLD albedo) users are very good for the unshielded runs (i.e., runs 1 and 2). As determined from Table 15, the median values for these runs are within $14 \%$ of the reference values and the mean values are within $11 \%$ of the reference values. In contrast, the TLD results for the shielded runs (i.e., runs 3-6) are not good. The mean and median values for these runs are higher than the reference values by factors of 1.6-2.0." When a shield is placed between the HPRR and the dosimeters, the dosimeters are exposed to neutrons of lower average energy than if they are unshielded. It is probable that the relatively high dose equivalents reported for the shielded runs are due to the fact that TLD-albedo dosimeters are "extremely energy dependent and overrespond severezy to low energy neutrons." 10 The relative response of a TLD-albedo dosimeter increases by about a factor of 10 as the neutron energy drops from $2 \mathrm{MeV}$ to 0.2 MeV. ${ }^{9}$.

\section{Gamimà Dose-Phảntóm Frỏnt}

Gamma dose equivalent results from measurements made on the front of phantoms are summarized in Table 16. When all reported results are

* The reader is reminded that this analysis does not include the extremely high TLD results from RPB and UTAH. 
considered, the mean values of the dose equivalent for the six runs are higher than the reference values by factors of 2.6-8.1 and have standard deviations of $124-165 \%$. The median values vary from 1.0-2.9 times the reference values.

The IRA group did not know the neutron sensitivity of their gamma dosimeter system and UW obviously (reported values 7.5-33 times the reference value) had difficulty in dose determination. Groups specifying use of TLD-100 dosimeters (which are relatively neutron sensitive) generally reported very high results indicating insufficient correction for the neutron response. The IRA, UW, and specified TLD-100 data were subsequently omitted from the reported values and the statistical analysis of the data redone and included in Table 16 as a "Subset of reported results." These data should be more representative of the overall participant ability to measure gamma dose. The means are higher than the reference values by factors of 1.2-2.6 and have standard deviations of $39-172 \%$. The median values vary from $0.9-1.9$ times the reference values. For gamma dose equivalents in the range 0.1-1 $\mathrm{mSv}$ (10-100 mrem), measured in the presence of a larger neutron dose, these data indicate that almost all reported dose values are larger than the reference dose and that it is not unusual for results to differ by a factor of 3 to 4 .

A summary of the gamma dose equivalent as measured by various dosimeter types is presented in Table 17. Film did not provide good measurements of the gamma dose equivalent. In contrast to the filmmeasured neutron dose equivalent, the gamma results were generally high: 
the median values ranged from 0.9 to 4.1 times the reference values for the six runs and the mean values were 1.9-3.8 times the reference values. Almost all radiation monitoring film is somewhat sensitive to neutrons. Tests ${ }^{21}$ conducted on eight commercial film types used to measure gamma-rays showed that they were, on the average, four times ${ }^{*}$ more sensitive to thermal neutrons (on a gray or a rad basis) than to ${ }^{60}$ Co gamma-rays. The fast neutron response (per gray or rad) averaged only about $5 \%{ }^{\dagger}$ of the gamma response. Depending on the type of $f i 1 \mathrm{~m}$ used in the PDIS and whether or not the users corrected for such neutron sensitivity, this sensitivity could be a significant contributor to the high gamma doses reported.

The TLD gamma dose measurements (wi thout IRA, UW, and TLD-100 user data) are also presented in Table 17. They are generally much closer to the reference values than the film results, but are somewhat high: the median values range from 0.9-1.6 times the reference values while the means are 0.8-1.7 times the reference values for all runs except number 2 where a single exceptionally high result biased the remaining data. In every case, the mean values were within one standard deviation of the reference value.

Table 17 also includes the gamma dose equivalent as measured by TLD-100 users. It is readily seen why these results were omitted from the overall data analysis as being nonrepresentative of the general ability to measure gammas in the presence of neutrons: the means and medians are higher than the reference values by factors of about 3.5 for

\footnotetext{
* Some individual types were ten times more sensitive.

${ }^{\dagger}$ One individual type had a fast neutron response which was $23 \%$ of the gamma response.
} 
the unshielded runs, 5.5 for the Lucite shielded runs, and 10 for the concrete shielded runs. The TLD-100 dosimeters respond to neutrons as

well as to gamma-rays. " The gamma dose can be grossly overestimated unless careful spectrum-dependent corrections are made. As is observed in the PDIS data, the amount of overestimation is known to increase as the percentage of low energy neutrons increases. 22

\section{Neutron Dose-Phantom Rear}

Neutron dose equivalent results from measurements made on the rear ${ }^{\dagger}$ of the phantoms are summarized in Table 18. As is the case for measurements on the fronts of the phantoms, the film results are lower than the reference values and the TLD results are higher. No further statements about these data are presented because of the lack of enough data to provide statistical significance and the fact that the RPB TLD results (known to be calibrated to a distinctly different spectrum) are the only TLD measurements reported for three of the six runs.

\section{Gamma Dose-Phantom Rear}

Gamma dose equivalent results from measurements made on the rear of the phantoms are summarized in Table 19. For most cases, the means are within one standard deviation of the reference values. That would normally be an indication of good data, but here it is due to very large standard deviations. These data are presented for completeness of reporting, but are not used to draw conclusions because of the relatively few results reported. In addition, the values in Table 19 include UW

* The TLD-100 material is natural lithium fluoride and contains $7.5 \%$ of the $\sigma_{L} i$ isotope which is extremely sensitive to thermal neutrons.

the rear of the phantom is the surface the greatest distance from the HPRR (see Fig. 3). 
values (as previously mentioned, UW obviously had measurement difficulty) and, as could be expected, exceptionally high values from a TLD-100 user.

\section{CONCLUSIONS}

Conclusions based on the results of the fifth PDIS are:

1) Interest in radiation dosimetry intercomparison studies is increasing.

2) The most popular types of personnel dosimeters are TLD-albedo for neutron measurements and TLD for gamma measurements.

3) For measurements of neutron dose equivalent in the 1-15 mSv (100-1500 mrem) range, it is not unusual for results reported by various groups to differ by a factor of 2 to 3. *

4) Neutron dose equivalents are much more accurately measured in the unshielded runs than in the shielded ones.

5) About $55 \%$ of the reported neutron dose equivalent values are hlyher than the reference duse. This is an indicaliun lhal there is no real bias among the results as a whole.

6) The mean and median values of neutron dose equivalent measurements reported by users of film dosimeters are less than $40 \%$ of the reference dose. This indicates that film is inadequate for this application.

7) Track dosimeters, in general, provided more accurate neutron dose equivalent measurements than did TLD or film.

8) For gamma dose equivalent measurements in the 0.1-1 mSv (10$100 \mathrm{mrem})$ range with relatively large numbers of neutrons

\footnotetext{
*This is true even after the "far out" data have been omitted.
} 
present, it is not unusual for reported results to differ by a factor of 3 to 4. *

9) About $80 \%$ of the reported gamma dose equivalent values are higher than the reference dose. This is probably primarily due to a failure to account properly for the neutron sensitivity of the gamma dosimeters used in the study.

10) In genera1, TLD measurements of the gamma dose equivalent are more accurate than film measurements.

11) Gamma dose equivalents are slightly more accurately measured in the unshielded runs than in the shielded ones.

12) The TLD-100 dosimeters are generally unsuitable for the measurement of gamma dose equivalent in mixed neutron-gamma radiation fields.

\section{EPILOGUE}

It is hoped that the PDIS study participation and the results presented in this report will encourage and challenge many groups to learn more about the limitations of their dosimetry systems. It appears that several groups could significantly improve the accuracy of their results by using dosimeter types more suited to the measurement of particular types of radiation or by giving greater attention to the response characteristics of their dosimeters and making corrections based on those characteristics and knowledge of the spectrum being measured. Improved dose estimates can be obtained in the manner suggested, but the "bottom line" is this: more research and development work is needed in mixed field radiation dosimetry.

"This is true even after the "far out" data have been omitted. 


\section{REFERENCES}

1. H. W. Dickson, W. F. Fox, and F. F. Haywood, 1974 Intercomparison of Personnel Dosimeters, ORNL/TM-4786 (January 1976).

2. L.W. Gilley, H.W. Dickson, and D. J. Christian, 1976 Intercomparison of Personnel Dosimeters, ORNL/TM-5672 (December 1976).

3. L. W. Gilley and H.W. Dickson, Third Personnel Dosimetry Intercomparison Study, ORNL/TM-6114 (January 1979).

4. H. W. Dickson, Fourth Personnel Dosimetry Intercomparicon Study, กRNI /TM-7137 (in preparation),

5. J. A. Auxier, "The Health Physics Research Reactor," Hearth Phys. 11, 89-93 (1965).

6. C. S. Sims, Fifteenth Nuclear Accident Dosimetry Intercomparison Study: August 14-22, 1978, ORNL/TM-6554 (May 1979).

7. J. W. Poston, J. R. Knight, and G. E. Whitesides, "Calculation of the HPRR Neutron Spectrum for Simulated Nuclear Accident Conditions," Ileazth Fhyo, 26, 217-221 (1974).

8. F. W. Sanders and J. A. Auxier, "Neutron Activation of Sodium in Anthropomorphous Phantoms," Health Phys. 8, 371-379 (1962).

9. T. P. Barton and C. E. Easterly, Neutron Personnel Dosimetry Considerations for H'usion keactors, ORNL/TM-6756 (July 1979).

10. R. V. Griffith, D. E. Hankins, R. B. Gammage, L. Tommasino, and R. V. Wheeler, "Recent Developments in Personnel Neutron Dosimeters A Review," Health Phys. 36, 235-260 (1979).

11. E. B. Wagner and G. S. Hurst, "A Geiger-Mueller $\gamma$-Ray Dosimeter with Low Neutron Sensitivity," Health Phys. 5, 20-26 (1961).

12. D. R. Johnson and J. W. Poston, Radiation Dosimetry Studies at the Health Physics Research Reactor, ORNL-4113 (June 1967). 
13. C. S. Sims and H. W. Dickson, "Nuclear Accident Dosimetry Intercomparison Studies at the Health Physics Research Reactor: A Summary (1965-1978)," Health Phys. 37, 687-699 (1979).

14. M.S.S. Murthy, R. C. Bhatt, and S. S. Shinde, "Estimation of Quality Factor and RBE for Degraded Fission Neutron Spectra," Hearth Phys. 27, 9-17 (1974).

15. C. S. Sims, H.W. Dickson, and L.W. Gilley, "Neutron Quality Factor Measurements at the Oak Ridge National Laboratory's Dosimetry Applications Research Facility," to be published in Health Physics.

16. J. A. Auxier, W. S. Snyder, and T. D. Jones, "Neutron Interactions and Penetration in Tissue," Radiation Dosimetry, Vol. 1, p. 275, ed. by F. H. Attix and W. C. Roesch, Academic Press, New York (1968).

17. H. W. Dickson, Unpublished hand calculations using a Monte Carlo calculated spectrum for the concrete shielded HPRR (1979).

18. International Commission on Radiation Units and Measurements, Radiation Protection Instrumentation and Its Application, ICRU Report 20 (1971).

19. L. J. Goodman, "Density and Composition Uniformity of A-150 TissueEquivalent Plastic," Phys. Med. Biol. 23, 4 (1978).

20. C. S. Sims and H.W. Dickson, "Health Physics Research Reactor Spectrum Measurements with Threshold Detector Units," to be published in Health Physics.

21. Robert J. Smith and Ralph F. Benck, "Thermal and Fast Neutron Effects on Dosimeter Films," Health Phys. 9, 473-484 (1963).

22. Dale E. Hankins, "Evaluation of the Fast Neutron Dose Equivalent Using the Thermal Neutron Response of LiF TL Material," Health Phys. 31, 170-173 (1976). 

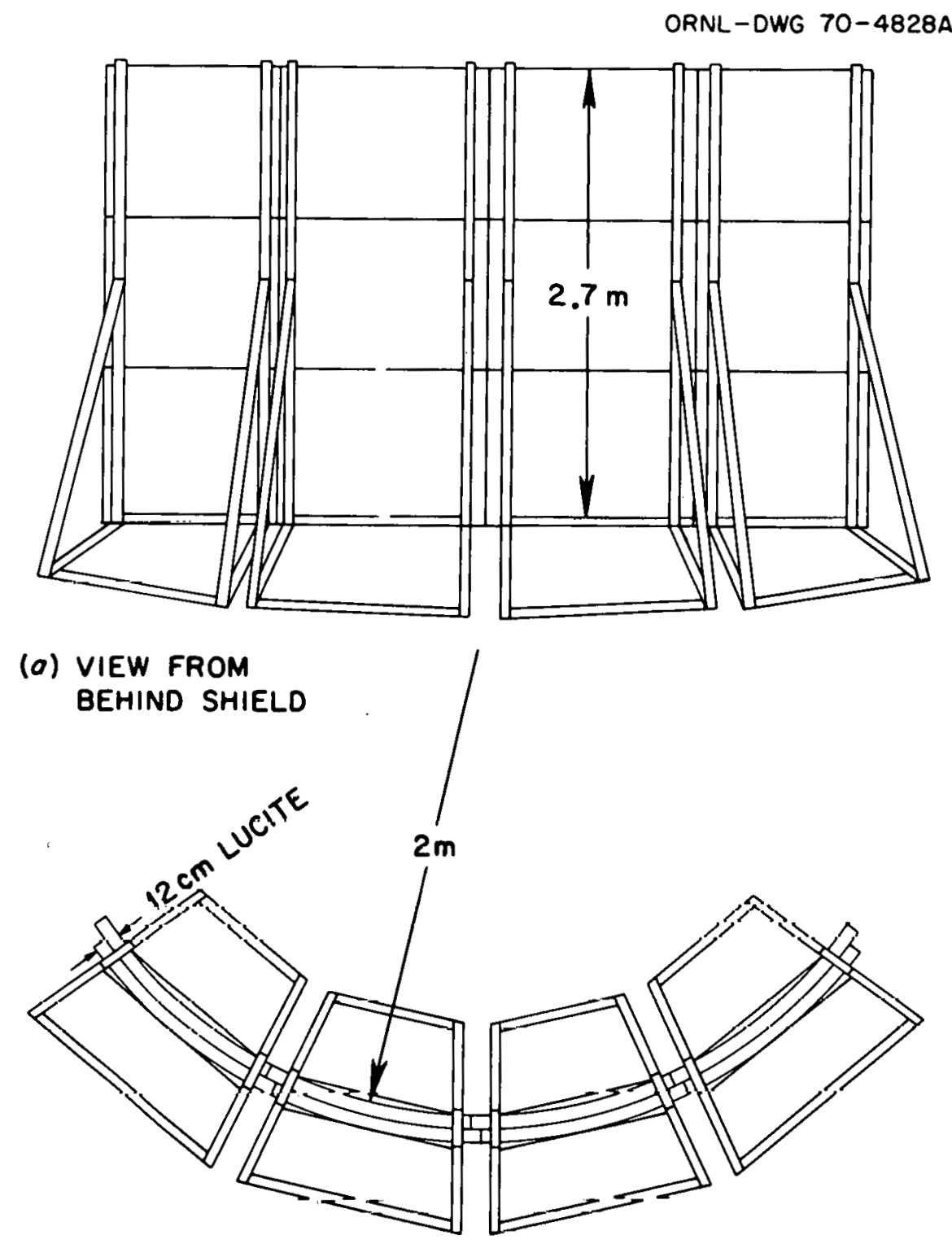

(b) VIEW LOOKING DOWN FROM ABOVE SHIELD

Fig. 1. Lucite shield. 


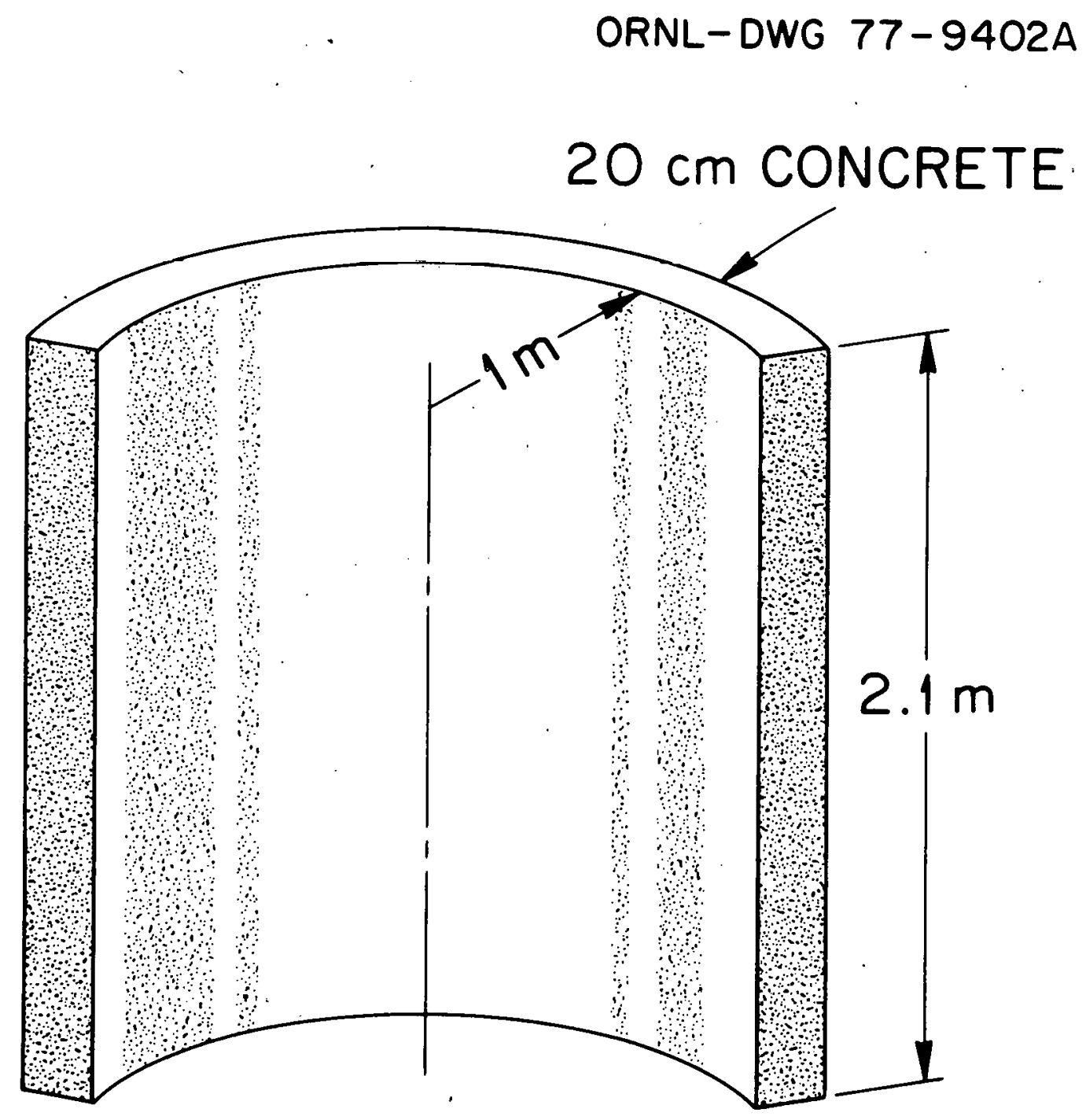

Fig. 2. Concrete shield. 
ORNL-DWG 79-19734

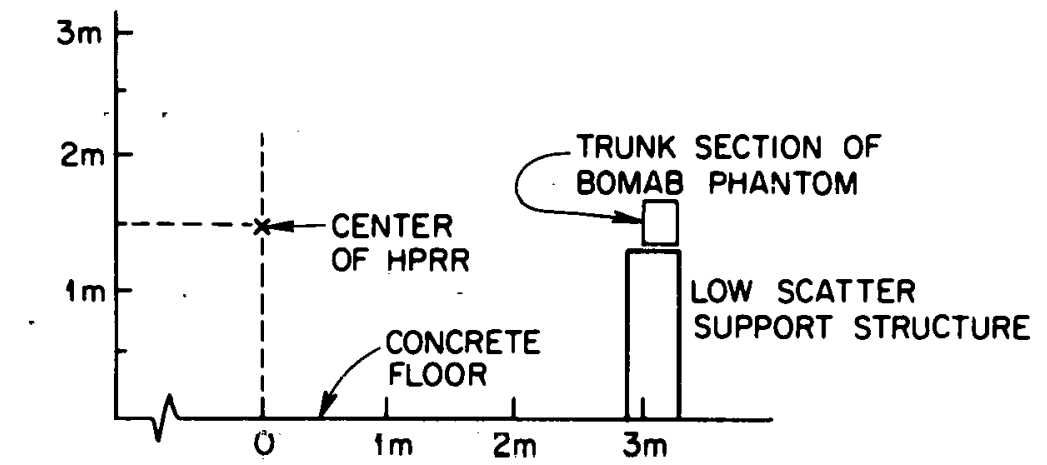

(a) EXPOSURES 1 AND 2

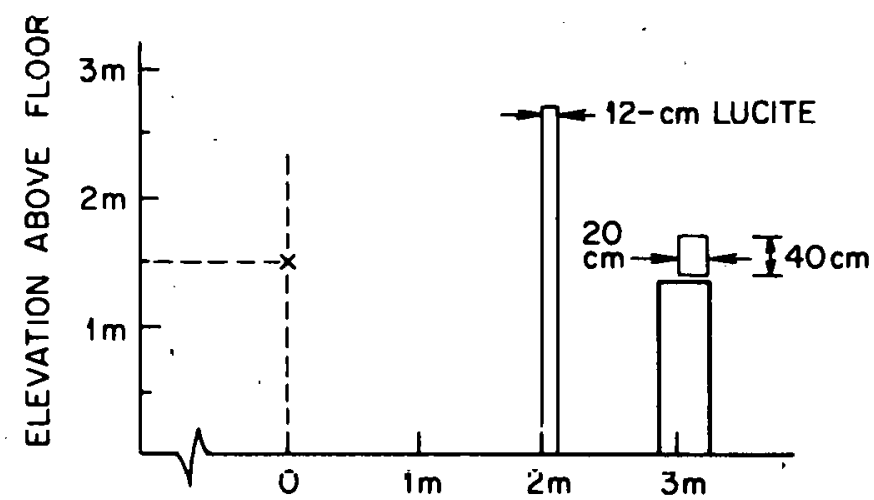

(b) EXPOSURES 3 AND 4

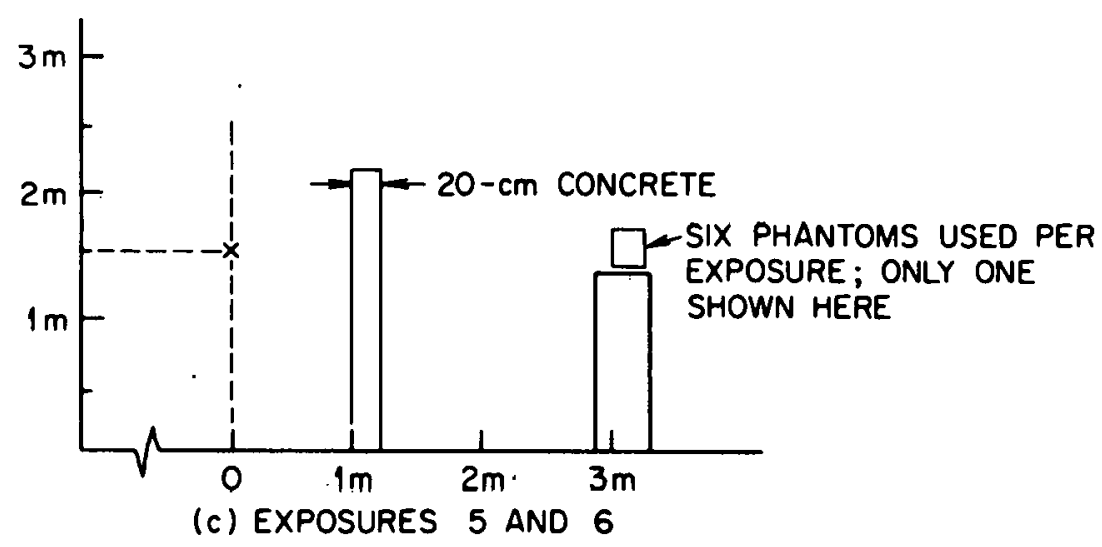

Fig. 3. Experimental arrangement for PDIS exposures. 
Table 1. Summary of experimental conditions

\begin{tabular}{|c|c|c|c|c|c|c|c|c|}
\hline $\begin{array}{l}\text { Exposure } \\
\text { number }\end{array}$ & $\begin{array}{l}\text { Date of } \\
\text { exposure }\end{array}$ & $\begin{array}{l}\text { Start } \\
\text { time }^{a}\end{array}$ & $\begin{array}{l}\text { Exposure } \\
\text { duration, } \\
\text { s }\end{array}$ & $\begin{array}{c}\text { Reactor } \\
\text { power, } \\
w\end{array}$ & $\begin{array}{c}10^{-13} \times \\
\text { number } \\
\text { of fissions }\end{array}$ & $\begin{array}{l}\text { Shield } \\
\text { thickness } \\
\text { and type }\end{array}$ & $\begin{array}{l}\text { Shield } \\
\text { distance from } \\
\text { reactor, } m\end{array}$ & $\begin{array}{l}\text { Distance from } \\
\text { reactor to front } \\
\text { of phantom, } b \mathrm{~m}\end{array}$ \\
\hline 1 & $3 / 20 / 79$ & 1031 & 503 & 0.20 & 0.31 & None & & 3 \\
\hline 2 & $3 / 20 / 79$ & 1312 & 537 & 1.50 & 2.50 & None & & 3 \\
\hline 3 & $3 / 21 / 79$ & 0923 & 508 & 6.00 & 9.45 & $\begin{array}{l}\text { 12-cm } \\
\text { Lucite }\end{array}$ & 2 & 3 \\
\hline 4 & $3 / 21 / 79$ & 1122 & 576 & 2.00 & 3.57 & $\begin{array}{l}12-\mathrm{cm} \\
\text { Lucite }\end{array}$ & 2 & 3 \\
\hline 5 & $3 / 21 / 79$ & 1405 & 524 & 6.00 & 9.75 & $\begin{array}{l}20-\mathrm{cm} \\
\text { concrete }\end{array}$ & 1 & 3 \\
\hline 6 & $3 / 22 / 79$ & 0912 & 466 & 1.50 & 2.17 & $\begin{array}{l}20-\mathrm{cm} \\
\text { concrete }\end{array}$ & 1 & 3 \\
\hline
\end{tabular}

${ }^{a}$ Eastern Standard Time.

${ }^{b}$ The horizontal centerlines of the reactor and of the phantom sections on which the dosimeters were mounted were $1.5 \mathrm{~m}$ above the concrete floor for a 11 exposures. 
Table 2. Dosimeters as described by the participants

\begin{tabular}{|c|c|c|}
\hline Group $^{a}$ & $\begin{array}{l}\text { Neutron } \\
\text { dosimeter }\end{array}$ & $\begin{array}{c}\text { Gamma } \\
\text { dosimeter }\end{array}$ \\
\hline ANL & TLD-albedo & TLD \\
\hline BMI & P-1 type film & LiF TLD and film \\
\hline BUMED & LiF TLD & LiF TLD \\
\hline CERN & Film & Film \\
\hline DOSAR & \multicolumn{2}{|c|}{ See reference dosimetry section } \\
\hline EIC & TLD $=100$ & TLD-100 \\
\hline \multicolumn{3}{|l|}{ EUR-LUX } \\
\hline \multicolumn{3}{|l|}{ FERMI } \\
\hline GAC & & Harshaw TLD and film \\
\hline GFK & TLD albedo, recoil track & TLD-700 \\
\hline IRA & & TLD \\
\hline IRD-CS & Track with Th and U & $\mathrm{CaSO}_{4}: \mathrm{Dy}$ TLD \\
\hline KSU & Film (Rad. Det. Co.) & Film (Rad. Det. Co.) \\
\hline LAND & Neutrak, CR-39 & \\
\hline ND & & Landauer fillil badges \\
\hline NRPB & Neutron emulsion & \\
\hline OPPD & Harshaw TLD-600 & Harshaw TLD-700 \\
\hline $\begin{array}{l}\text { PPPL } \\
\text { REECO }\end{array}$ & $\begin{array}{l}\text { Landauer } \mathrm{H}-1 \text { film badge } \\
{ }^{6} \mathrm{Li} /{ }^{7} \mathrm{Li} \text {; Cd-encased }\end{array}$ & $\begin{array}{l}\text { Landauer } H=1 \text { ri } 1 \text { II badye } \\
{ }^{L} \mathrm{Li} /{ }^{7} \mathrm{Li} ; \mathrm{Cd} \text {-encased }\end{array}$ \\
\hline RFP & TLD a bedo & TLD-700 \\
\hline \multicolumn{3}{|l|}{ RMC } \\
\hline RPB & TLD albedo & LiF-100 (TLD) \\
\hline \multicolumn{3}{|l|}{ SK } \\
\hline SLA & TLD a bedo & LIF TLU \\
\hline TVA & ${ }^{6}$ LiF TLO albedo & TLD-700 \\
\hline$U C D$ & Film badge & Film badge \\
\hline UTAH & TLD-100 LiF & TLD-100 LiF \\
\hline IJW & & Rad. Det. Co. TLD badge \\
\hline YALE & Landauer Gardray & Landauer Gardray \\
\hline
\end{tabular}

$a_{\text {Identifying acronyms are defined in Appendix } A .}$ 
Table 3. Reference gamma dose equivalent

\begin{tabular}{|c|c|c|c|c|c|}
\hline \multicolumn{5}{|c|}{ Phantom front } & Phantom rear \\
\hline $\begin{array}{l}\text { Run } \\
\text { Number }\end{array}$ & $\frac{\text { Gas }}{\text { TLD }}$ & $\begin{array}{c}\text { dose equi } \\
\text { G-M on } \\
\text { phantom }\end{array}$ & $\begin{array}{l}\text { ent, } 10^{-5} \mathrm{~Sv}^{a} \\
\text { Inferred from } \\
\text { G-M in air }\end{array}$ & $\begin{array}{c}\text { Reference gamma dose } \\
\text { equivalent, } b 10^{-5} \mathrm{~Sv} \\
\text { (average of three methods) }\end{array}$ & $\begin{array}{l}\text { Reference gamma dose } \\
\text { equivalent, } b 10^{-5} \text { Sv } \\
\text { (TLD measured) }\end{array}$ \\
\hline 1 & 10.7 & 9.0 & 12.8 & 11 & 5 \\
\hline 2 & 34.5 & 30.4 & 33.2 & 33 & 17 \\
\hline 3 & 102.0 & 86.6 & 103.0 & 97 & 29 \\
\hline 4 & 25.6 & 34.1 & 41.7 & 34 & 10 \\
\hline 5 & 32.3 & 42.9 & 38.7 & 38 & 10 \\
\hline 6 & 7.9 & 9.6 & 9.7 & 9 & 3 \\
\hline
\end{tabular}

$a_{1 \text { mrem }}=10^{-5} \mathrm{~Sv}$.

$b_{\text {Rounded to the nearest whole number. }}$ 
Table 4. Meutron dose equivalent from sulfur pellet analysi:

\begin{tabular}{|c|c|c|c|c|c|c|c|c|}
\hline Run & $\begin{array}{l}\text { Unshielded dose } \\
\text { at area monitor, } \\
10^{-5} 5_{\mathrm{Gy}}\end{array}$ & $\begin{array}{l}\text { Sh'eld } \\
\text { factor }\end{array}$ & $\begin{array}{l}\text { Shielded dose } \\
\text { at area monitor, } \\
10^{-5}{ }^{-\mathrm{Gy}}\end{array}$ & $\begin{array}{l}\text { A.rea monitor to } \\
\text { phantom dose } \\
\text { conversion }\end{array}$ & $\begin{array}{l}\text { Quality } \\
\text { factor }\end{array}$ & $\begin{array}{c}\text { Dose equivalent } \\
\text { on phanitom frorit, } \\
10^{-5} \mathrm{~Sv}\end{array}$ & $\begin{array}{l}\text { Phantom front } \\
\text { to rear } \\
\text { conversion }\end{array}$ & $\begin{array}{c}\text { Dose equivaient } \\
\text { on phantom rear, } \\
10^{-5} \mathrm{~Sv}\end{array}$ \\
\hline 1 & 14 & & 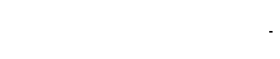 & 1.04 & 9.4 & 137 & 0.16 & 22 \\
\hline 2 & 108 & & & 1.04 & 9.4 & $105 j$ & 0.16 & 169 \\
\hline 3 & $387^{\circ}$ & 0.152 & 58.8 & 1.03 & 8.9 & $53: 9$ & 0.21 & 113 \\
\hline 4 & 149 & 0.152 & 22.7 & 1.03 & 8.9 & 208 & 0.21 & 44 \\
\hline 5 & 329 & 0.185 & 60.9 & 1.20 & 9.8 & 716 & 0.19 & 136 \\
\hline 6 & 76 & 0.785 & 14.1 & 1.20 & 9.8 & 165 & 0.19 & 31 \\
\hline
\end{tabular}

Note: 1. mrad $=10^{-5}$ fy, 1 mren $=10^{-5} \mathrm{~Sv}$.

Table 5. Neutron dose equiva ${ }^{-}$ert from tissue equivalent ionization chamber measurenents

\begin{tabular}{|c|c|c|c|c|c|c|c|c|}
\hline Run & $\begin{array}{l}\text { Measured neutron and } \\
\text { gamma dose at area } \\
\text { monitor, } 10^{-5} \text { Gy }\end{array}$ & $\begin{array}{l}\text { Measured gamma } \\
\text { dose } a=\text { area } \\
\text { monitor. } 10^{-5} \text { ry }\end{array}$ & $\begin{array}{l}\text { Inferred neutron } \\
\text { dose } a \pm \text { area } \\
\text { monitor. } 10^{-3} \text { Gy }\end{array}$ & $\begin{array}{l}\text { Area monitor to } \\
\text { phantom dose } \\
\text { conversion }\end{array}$ & $\begin{array}{l}\text { Quality } \\
\text { factor }\end{array}$ & $\begin{array}{l}\text { De se equivalent } \\
\text { an phantom } \\
\text { iront, } 10^{-5} \text { Sv }\end{array}$ & $\begin{array}{l}\text { Phantom front } \\
\text { to rear } \\
\text { conversion }\end{array}$ & $\begin{array}{l}\text { Dose equivalent } \\
\text { on phantom } \\
\text { rear, } 10^{-5} \mathrm{~Sv}\end{array}$ \\
\hline 1 & 22.7 & 77 & 15.0 & 1.04 & 9.4 & $14 ?$ & 0.16 & 23 \\
\hline 2 & 1139.4 & 20.0 & 119.4 & 1.04 & 9.4 & 1167 & 0.16 & 187 \\
\hline 3 & 132.2 & 74.7 & 57.5 & 1.03 & 8.9 & 527 & 0.21 & 111 \\
\hline 4 & 52.2 & 30.2 & 22.0 & 1.03 & 8.9 & 202 & 0.21 & 42 \\
\hline 5 & 37.4 & 30.2 & $57 . \tilde{z}$ & 1.20 & 9.8 & 673 & 0.19 & 128 \\
\hline 6 & 19.8 & 7.6 & 12.2 & 1.20 & 9.8 & 143 & 0.19 & 27 \\
\hline
\end{tabular}

NOTE: 1 mrad $=10^{-5} \mathrm{~Gy}, 1$ mrem $=10^{-5} \mathrm{~Sv}$. 
Table 6. Neutron dose equivalent from calculations

\begin{tabular}{|c|c|c|c|c|c|c|c|c|c|}
\hline Run & $\begin{array}{c}\text { E ergy expended } \\
\text { Juring run as } \\
\text { determined by HPRR } \\
\text { instrumentation, } \\
\text { w-min }\end{array}$ & $\begin{array}{l}\text { Number of } \\
\text { fissions }\end{array}$ & $\begin{array}{l}\text { Neutron fluence } \\
\text { at phantom } \\
\text { front, } \mathrm{n} / \mathrm{cm}^{2}\end{array}$ & $\begin{array}{c}\text { Dose conversion } \\
\text { factor } \\
10^{-5} \mathrm{~Gy}-\mathrm{cm}^{2} / \mathrm{n}\end{array}$ & $\begin{array}{l}\text { Dose, } \\
10^{-5} \text { Gy }\end{array}$ & $\begin{array}{l}\text { Quality } \\
\text { factor }\end{array}$ & $\begin{array}{c}\text { Dose equivalent } \\
\text { on phantom } \\
\text { front, } 10^{-5} 5 v^{c}\end{array}$ & $\begin{array}{l}\text { Phantom } \\
\text { front to } \\
\text { rear } \\
\text { conversion }\end{array}$ & $\begin{array}{l}\text { Dose equivalent } \\
\text { on phantom } \\
\text { rear, } 10^{-5} \mathrm{~Sv}\end{array}$ \\
\hline 1 & 1.68 & $0.31 \times 10^{13}$ & $0.61 \times 10^{7}$ & $25.5 \times 10^{-7}$ & 15.6 & 9.4 & 147 & 0.16 & 24 \\
\hline 2 & 13.42 & $2.50 \times 10^{13}$ & $4.90 \times 10^{7}$ & $25.5 \times 10^{-7}$ & 125.0 & 9.4 & 1175 & 0.16 & 188 \\
\hline 3 & 50.30 & $9.45 \times 10^{13}$ & $5.04 \times 10^{7}$ & $14.6 \times 10^{-7}$ & 73.6 & 8.9 & 655 & 0.21 & 138 \\
\hline 4 & 19.22 & $3.57 \times 10^{13}$ & $1.90 \times 10^{7}$ & $14.6 \times 10^{-7}$ & 27.7 & 8.9 & 247 & 0.21 & 52 \\
\hline 5 & 52.38 & $9.74 \times 10^{13}$ & $9.74 \times 10^{7}$ & $13.5 \times 10^{-7}$ & 131.5 & 9.8 & 1289 & 0.19 & 245 \\
\hline 6 & 11.64 & $2.17 \times 10^{13}$ & $2.17 \times 10^{7}$ & $13.5 \times 10^{-7}$ & 29.3 & 9.8 & 287. & 0.19 & 55 \\
\hline
\end{tabular}

$2_{3 .} \times 10^{10}$ rissiors $=1 \mathrm{~W}-\mathrm{s}$.

$b_{1} \operatorname{mrad}=10^{-5} \mathrm{~Gy}$.

$c_{1}$ nrem $=10^{-5} \mathrm{~Sv}$. 
Table 7. Reference neutron dose equivalent

\begin{tabular}{lcc}
\hline & \multicolumn{2}{c}{ Reference neutron dose equivalent, $10^{-5} \mathrm{sv}^{\alpha}$} \\
\hline 1 & 142 & 23 \\
\hline 2 & 1112 & 178 \\
3 & 533 & 112 \\
4 & 205 & 43 \\
5 & 695 & 132 \\
6 & 154 & 29 \\
\hline & $a_{1 \mathrm{mrem}}=10^{-5}$.Sv, &
\end{tabular}


Table 8. Tabulation of reported results - POIS 5, run 1, unshielded

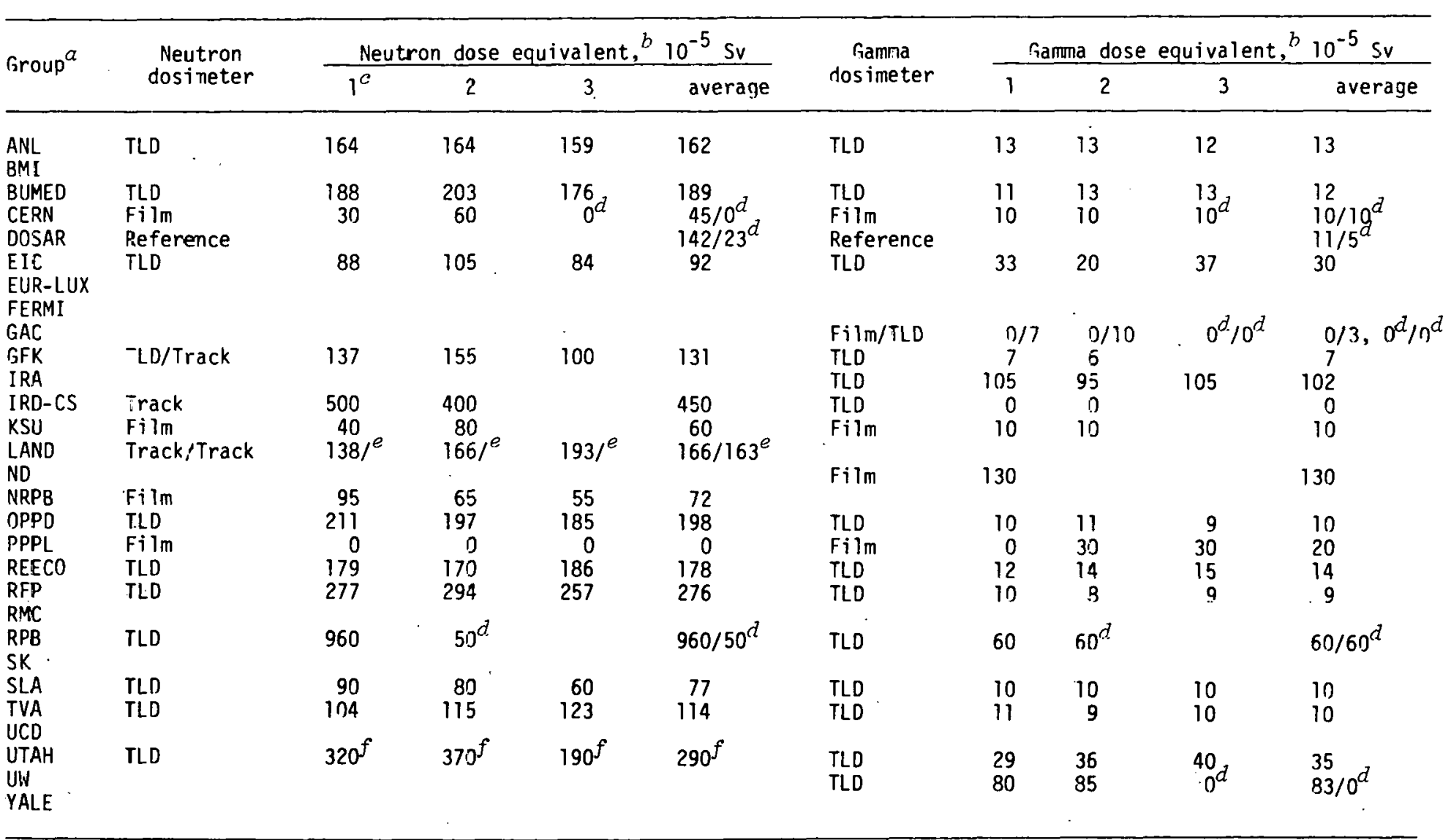

${ }^{a}$ Identifyirg acronyms are defined in Appendix A.

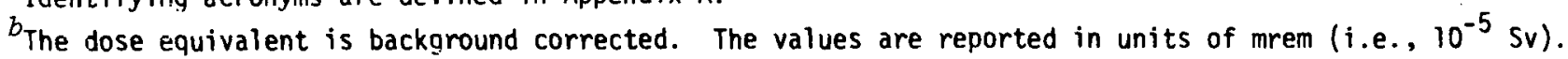

${ }^{c}$ Each group was allowed to expose three dosimeters per run.

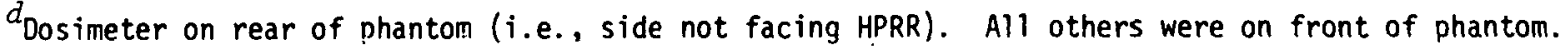

$e_{\text {Reported average of three. CR- } 39 \text { dosimeters. }}$

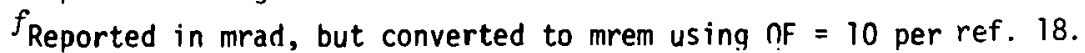


Table 9. Tabulaticn of reported results - FDIS 5, run ?, unshielded

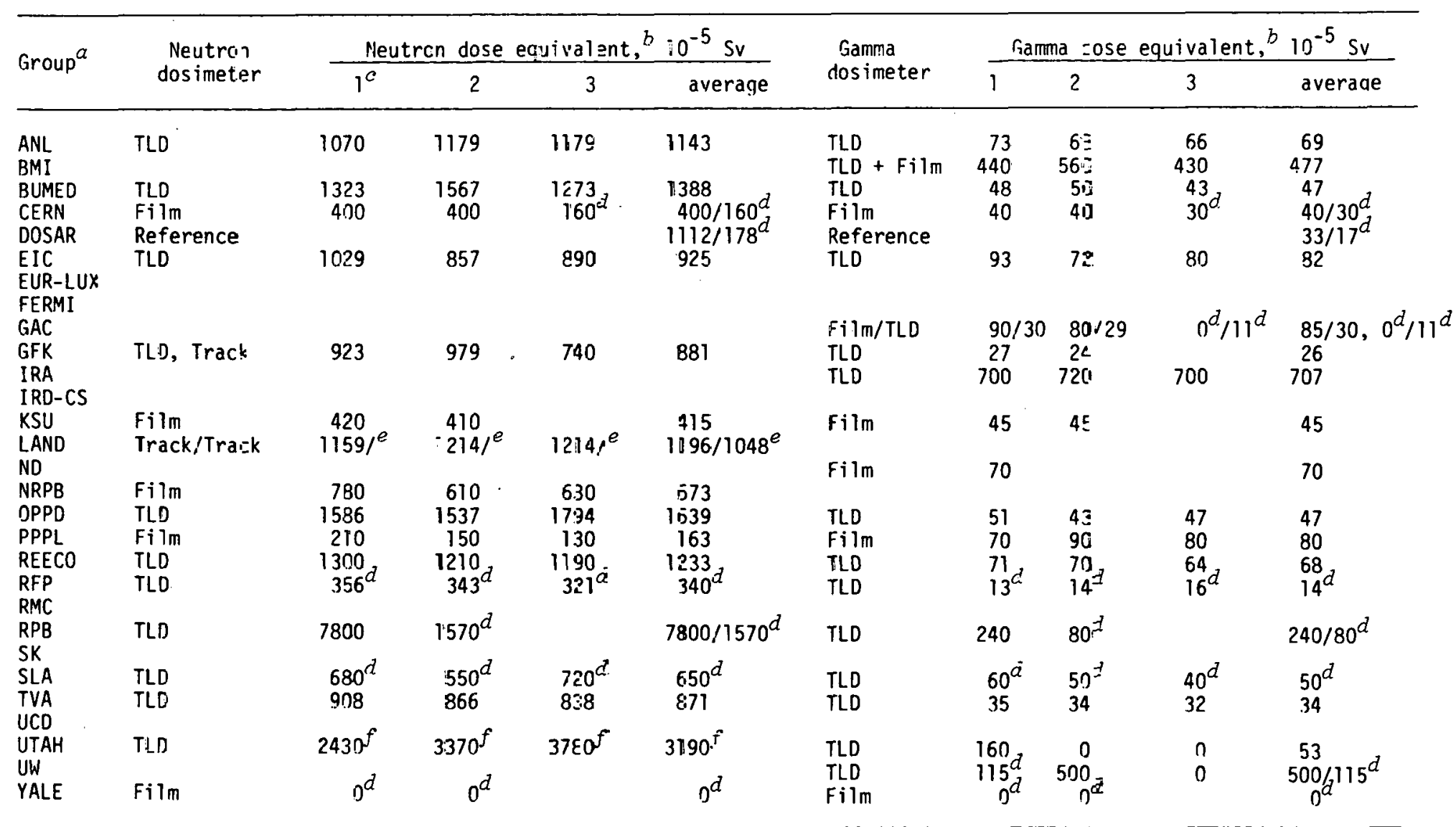

$a_{\text {Identifying ac'onyms are defined in Appeadix } f \text {. }}$

${ }^{b}$ The dose equivalent is background correcied. The values are reported in units of mrem $\left(\because . e ., 10^{-5} \mathrm{~Sv}\right)$.

${ }^{c}$ Each group was allowed to expose three dasineters pen run.

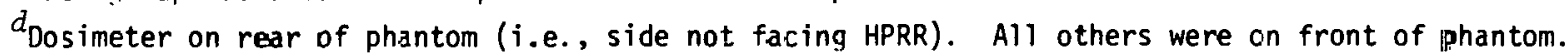

eRejorted average of three CR-39 dosimeters.

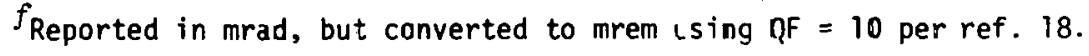


Table 10. Tabulation of reported results - PDIS 5, run 3 , Lucite shield

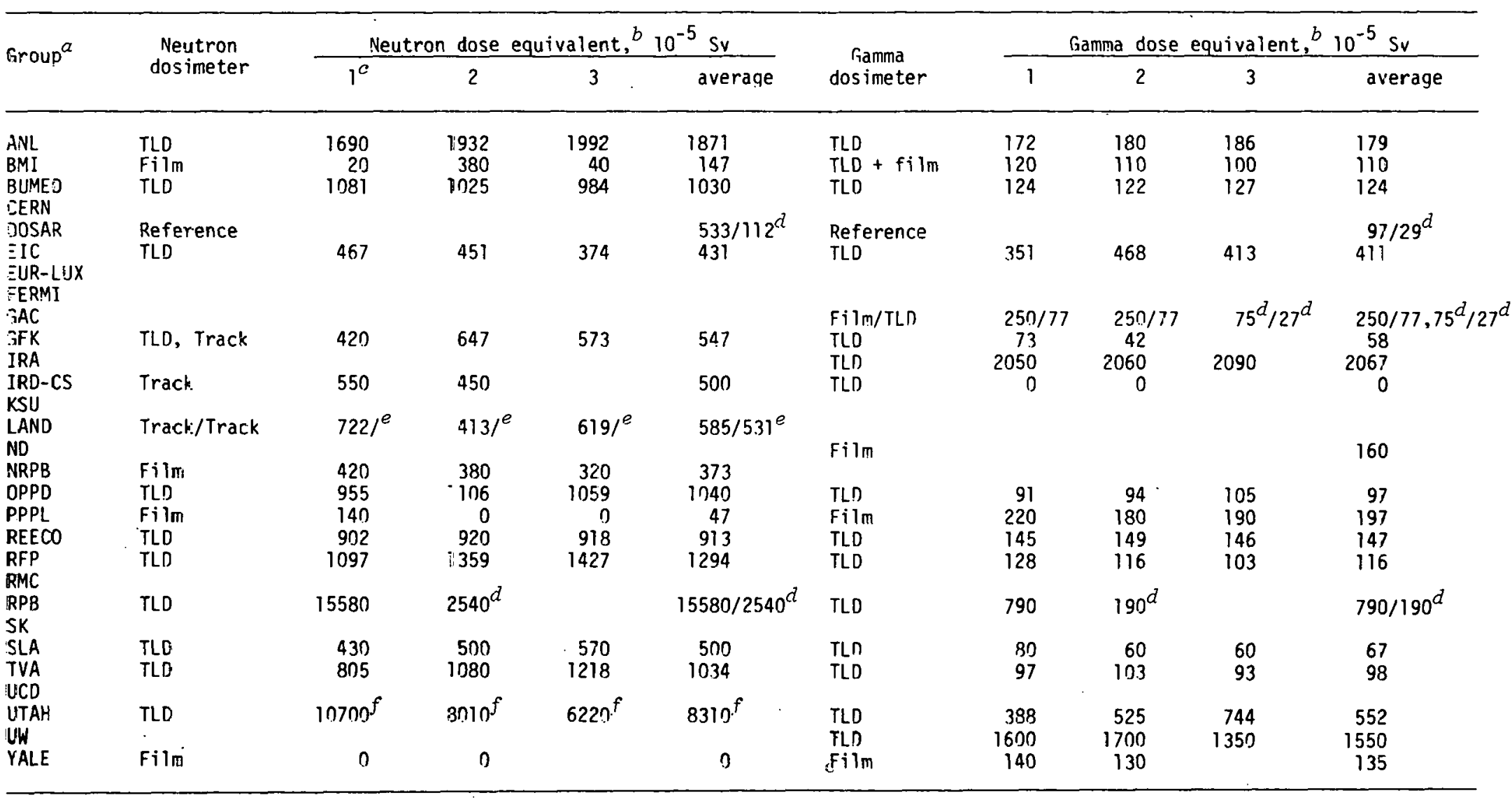

adentifyinn acronyms are defined in Appendix $A$.

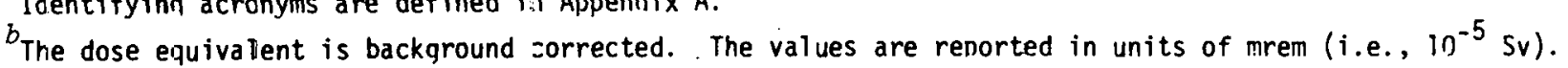

$c_{\text {Each }}$ aroup was allowed to expose three dosimeters per run.

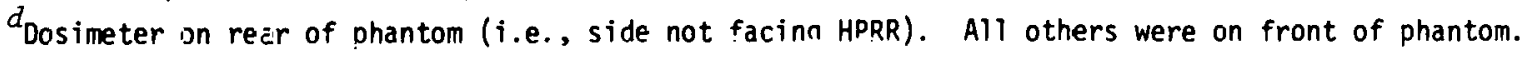

e Reported averane of three CR-39 dosimeters.

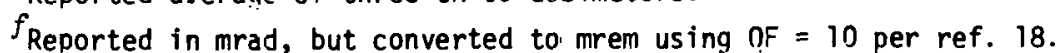


Table 11. Tabslation of repcrted results - PDIS 5, run 4, Lucite shield

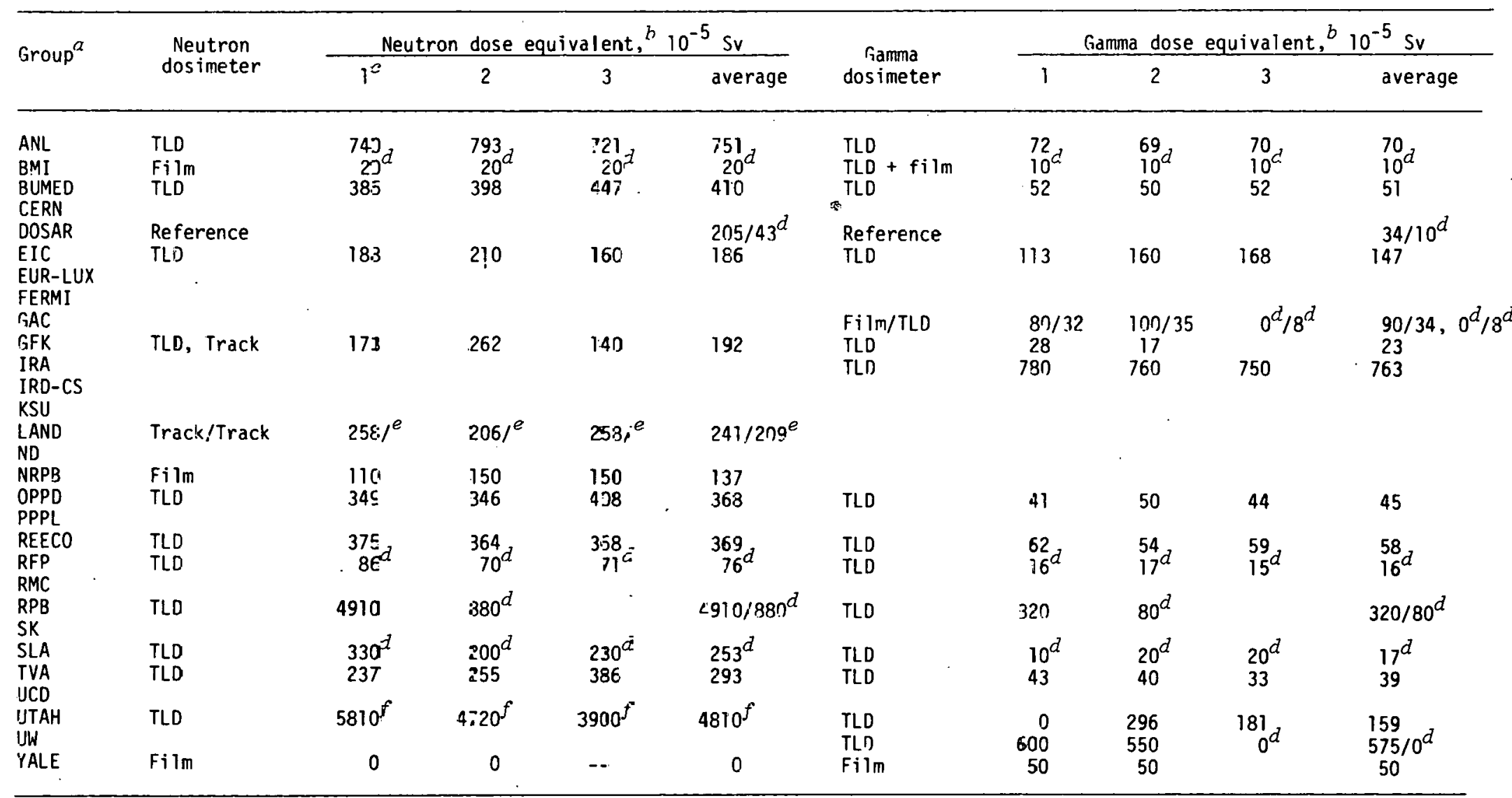

$a_{\text {Identifying acronys are de }}$ ined in Appendix $\lambda$.

${ }^{b}$ The dcse equivalent is background corrected. The values are reported in units of mrem (i.e.. $\left.10^{-5} \mathrm{~Sv}\right)$.

${ }^{c}$ Each group was allowed to expose three dosimezers per run.

doosimeter on rear of phanton (i.e., side not -acing HPRR). All others were on front af phanton.

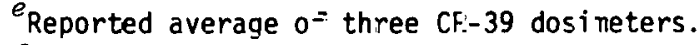

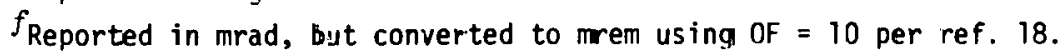


Table 12. Tabulation of reported results - PDIS 5, run 5, concrete shield

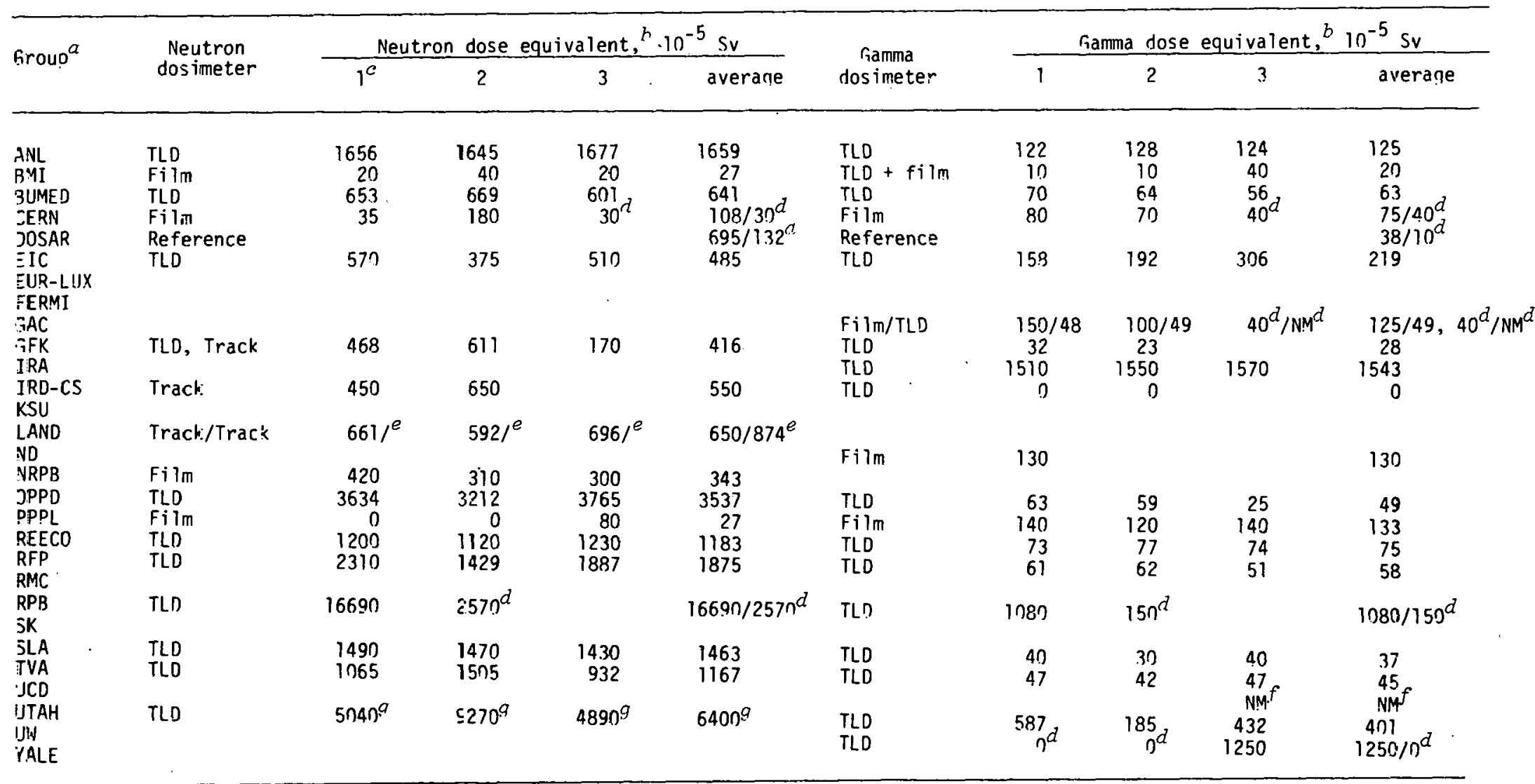

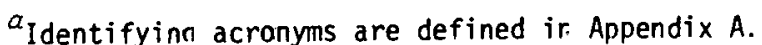

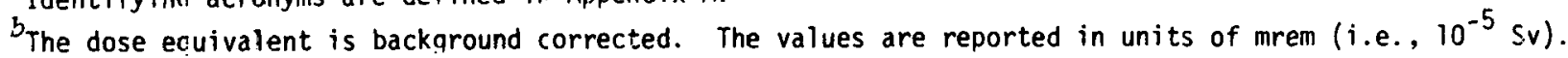

EEach group was allowed to expose three dosimeters per run.

dosimeter on rear of phantom (i.e. s side not facing HPRR). All others were on front of phantom.

Eeported average of three CR-39 dosimeters.

$f_{\text {NM }}=$ No TLD measurement taken.

${ }^{9}$ Reported ir: mrad, but converted to mrem using $\mathrm{OF}=10$ per ref. 18 . 
Table 13. Tajulation if reported results - PDIS 5, run 6 , concrete shield

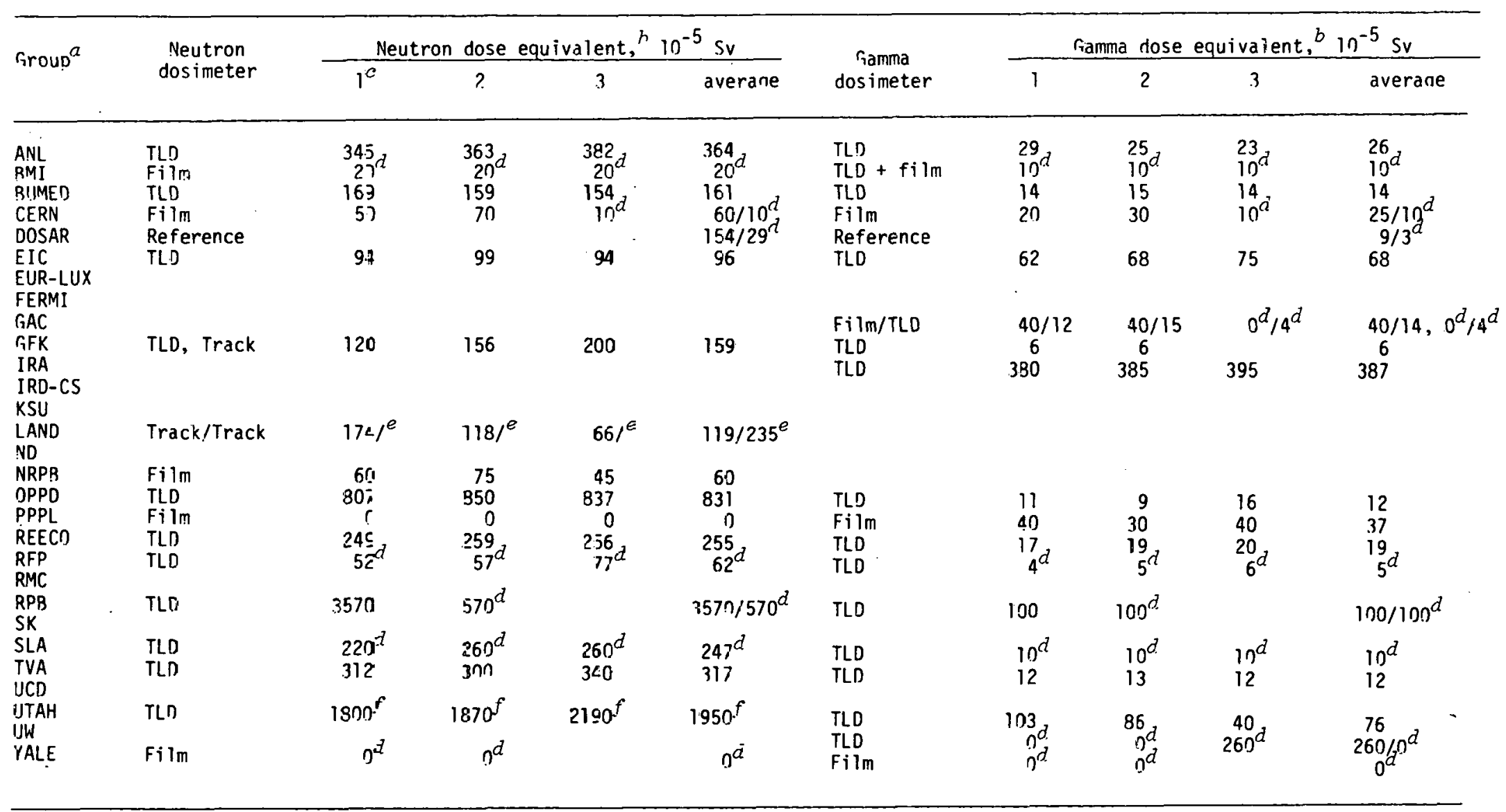

adentifyinn acronyns are defined in Appendix $A$.

b The dose equivalent is backcround corrected. The values are reported in units of mren (i.e., $\left.10^{-5} \mathrm{~Sv}\right)$.

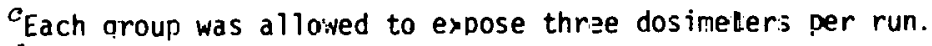

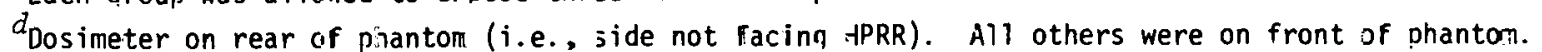

e Reported average of three CF-39 dosineters.

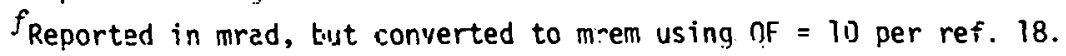


Table 14. Analysis of neutron dose equivalent results on front of phantoms

\begin{tabular}{lcccc}
\hline & \multicolumn{4}{c}{ Neutron dose equivalent, $10^{-5}$ sv (i.e., mrem) } \\
\cline { 2 - 4 } & 142 & $163,201 \pm 217(108)$ & $147,148 \pm 106(72)$ \\
2 & 1112 & $1048,1531 \pm 1871(122)$ & $925,921 \pm 422(46)$ \\
3 & 533 & $566,1930 \pm 3879(201)$ & $539,678 \pm 493(73)$ \\
4 & 205 & $293,990 \pm 1727(174)$ & $241,287 \pm 194(68)$ \\
5 & 695 & $762,2116 \pm 3948(187)$ & $646,938 \pm 896(96)$ \\
6 & 154 & $198,584 \pm 996(171)$ & $160,221 \pm 221(100)$ \\
\hline
\end{tabular}

$a_{\text {Values }}$ reported are median, mean $\pm \sigma(\% \sigma)$.

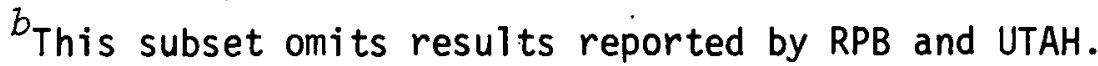


Table 15. Neutron dose equivalent on front of phantoms by type of dosimeter

\begin{tabular}{|c|c|c|c|c|}
\hline \multirow[b]{2}{*}{ Run } & \multicolumn{4}{|c|}{ Neutron dose equivalent, $10^{-5}$ Sv (i.e., mrem) } \\
\hline & Reference & Film & $\operatorname{Track}^{a}$ & $\operatorname{TLD}^{\alpha}$ \\
\hline 1 & 142 & $53,44 \pm 32(73 i$ & $166,260 \pm 165(63)$ & $162,157 \pm 62(39)$ \\
\hline 2 & 1112 & $408,413 \pm 208(50)$ & $1122,1122 \pm 105(9)$ & $1143,1154 \pm 290(25)$ \\
\hline 3 & 533 & $97,142 \pm 16: 6(117)$ & $531,539 \pm 43(8)$ & $1030,962 \pm 450(47)$ \\
\hline 4 & 205 & $69,69 \pm 97(141)$ & $225,225 \pm 23(10)$ & $368,367 \pm 191(52)$ \\
\hline 5 & 695 & $68,126 \pm 149(1.18)$ & $650,691 \pm 166(24)$ & $1183,1381 \pm 958(69)$ \\
\hline 6 & 154 & $60,40 \pm 35(88)$ & $177,177 \pm 82(46)$ & $255,312 \pm 248(79)$ \\
\hline
\end{tabular}

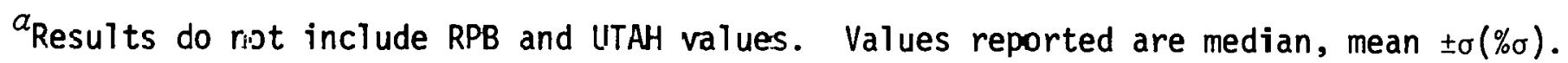


Table 16. Analysis of gamma dose equivalent results on front of phantoms

\begin{tabular}{lcccc}
\hline & \multicolumn{4}{c}{ Gamma dose equivalent, $10^{-5}$ sv (i.e., mrem) } \\
\cline { 2 - 3 } & Reference & A11 reported results & Subset of reported results \\
\hline 1 & 11 & $11,29 \pm 36(124)$ & $10,18 \pm 31(172)$ \\
2 & 33 & $69,150 \pm 200(133)$ & $47,86 \pm 119(138)$ \\
3 & 97 & $141,359 \pm 536(149)$ & $116,121 \pm 61(50)$ \\
4 & 34 & $64,173 \pm 227(131)$ & $50,51 \pm 20(39)$ \\
5 & 38 & $75,275 \pm 453(165)$ & $58,67 \pm 43(64)$ \\
6 & 9 & $26,73 \pm 108(148)$ & $17,21 \pm 11(52)$ \\
\hline
\end{tabular}

$a_{\text {Values }}$ reported are median, mean $\pm \sigma(\% \sigma)$. TLD- 100 .

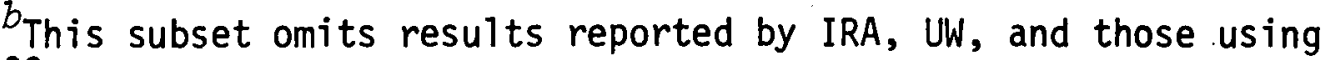


Table 17. Gamma dose equivalent on front of phantoms by tyfe of dosimeter

\begin{tabular}{lcccc}
\hline Run & \multicolumn{5}{c}{ Gama dose equivalent, $10^{-5}$ Sv (i.e., mrem) } & TLD $^{a} b$ & TLD-100 $^{a}$ \\
\cline { 2 - 5 } & Reference & \multicolumn{1}{c}{ Film $^{a}$} & $10,9 \pm 4(44)$ & $35,42 \pm 16(38)$ \\
2 & 11 & $70,34 \pm 54(159)$ & $47,100=153(153)$ & $82,125 \pm 101(81)$ \\
3 & 33 & $179,186 \pm 50 ! 27)$ & $98,98 \pm 48(49)$ & $522,574 \pm 195(34)$ \\
4 & 97 & $65,65 \pm 35(54)$ & $45,46 \pm 16(35)$ & $159,209 \pm 97(46)$ \\
5 & 34 & $125,97 \pm 49(51)$ & $49,53 \pm 33(62)$ & $401,567 \pm 454(80)$ \\
6 & 38 & $37,34 \pm 8 ! 24)$ & $14,15 \pm 6(40)$ & $76,81 \pm 17(21)$ \\
\hline
\end{tabular}

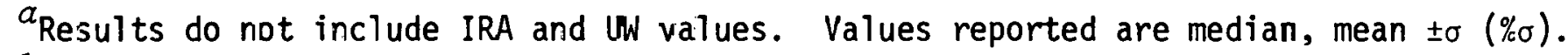

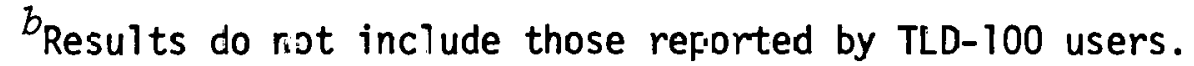


Table 18. Analysis of neutron dose equivalent results on rear of phantoms

\begin{tabular}{lclll}
\hline & \multicolumn{4}{c}{ Neutron dose equivalent, $10^{-5}$ Sv (i.e., mrem) } \\
\cline { 2 - 5 } & Reference & A11 reported results & \multicolumn{1}{c}{$\mathrm{Film}^{a}$} & \multicolumn{1}{c}{ TLD $^{a}$} \\
\hline 1 & 23 & $25,25 \pm 35(140)$ & $0^{b}$ & $50^{b}$ \\
2 & 178 & $340,544 \pm 622(114)$ & $80,80 \pm 113(141)$ & $650,853 \pm 640(75)$ \\
3 & 112 & $2540^{b}$ & $2540^{b}$ \\
4 & 43 & $165,307 \pm 395(129)$ & $20^{b}$ & $253,403 \pm 422(105)$ \\
5 & 132 & $1300,1300 \pm 1796(138)$ & $30^{b}$ & $2570^{b}$ \\
6 & 29 & $41,152 \pm 225(148)$ & $10,10 \pm 10(100)$ & $247,293 \pm 257(88)$ \\
\hline
\end{tabular}

$a_{V a l u e s}$ reported are median, mean $\pm \sigma(\% \sigma)$.

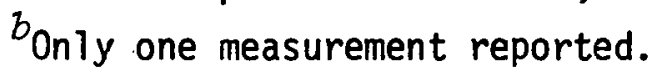


Table 19. Analysis o: gamma dcse equivalent results on rear of phantoms

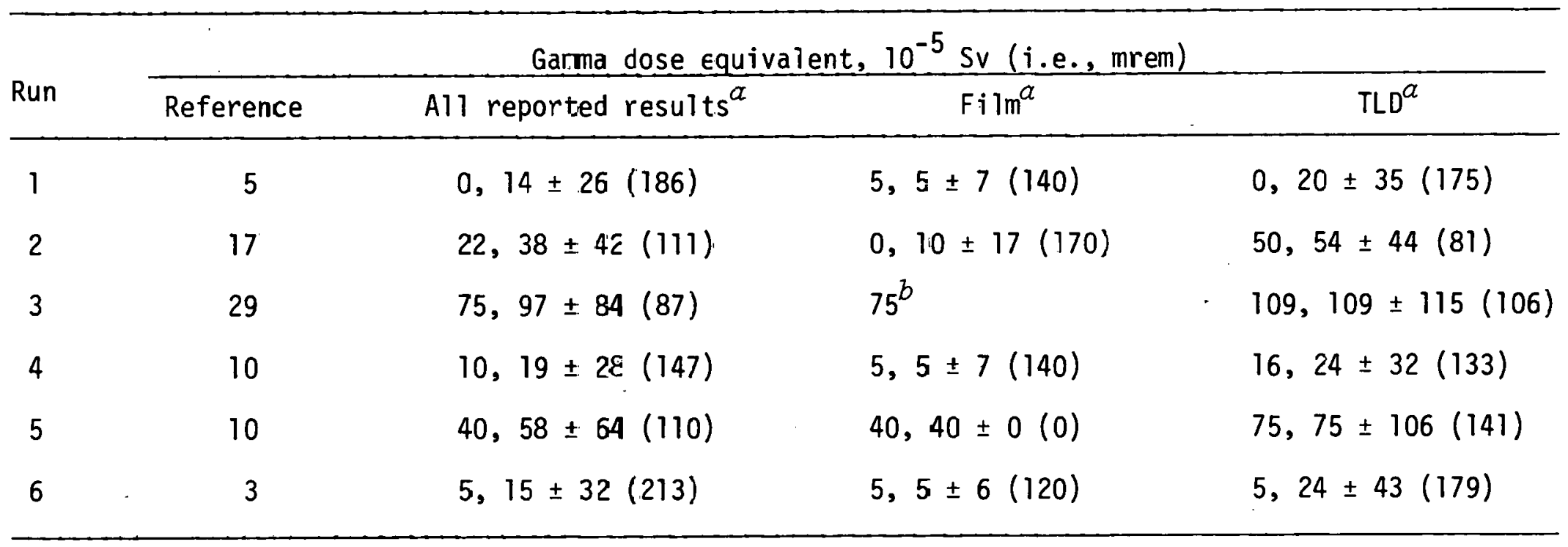

$a_{\text {Values }}$ repcirted are median, mean to $(\% \sigma)$.

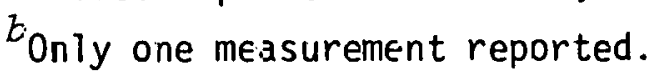


APPENDIX A 
THIS PAGE

WAS INTENTIONALLY

LEFT BLANK 
Study Participants

Name

W. E. Bleiler

George Kirsch

K. Goebel

J. Dutrannois

Frantisek Spurney

H. W. Dickson

L. W. Gilley

G. R. Patterson

C. S. Sims

E. Geiger

Rose Marie Tauche

Paul Lovendale

J. R. Ortman

Billy Short

J. F. Valley

M. Oberhofer
Affiliation

Argonne National Laboratory

9700 South Cass Avenue

Argonne, IL 60439

Battelle Memorial Institute

Columbus Laboratories

505 King Avenue

Columbus, $\mathrm{OH} \quad 43201$

CERN

European Organization for

Nuclear Research

Ch 1211 Geneve 23

Suisse, Switzerland

Czechoslovak Academy of Sciences

Institute of Radiation Dosimetry

$\mathrm{Na}$ Truhlarce $39 / 2 \mathrm{a}$.

18086 Praha 8,

Czechos lovakia

Dosimetry Applications Research

Oak Ridge National Laboratory

P. 0. Box $X$, Building 7710

Oak Ridge, TN 37830

Eberline Instrument Corporation

P. 0. Box 2108

Santa Fe, NM

87501

Fermilab

Batavia Road

Batavia, IL 60510

Goodyear Atomic Corporation

P. 0. Box 628

Piketon, $\mathrm{OH} 45661$

Institut de Radiophysique Appliquee

Centre Universitaire

1015 Lausanne

Swi tzerland

Joint Research Center

Ispra Establishment

Euratom C. C. R.

21020 Ispra (Varese)

Italy
Identifying abbreviation

ANL

BMI

CERN

IRD-CS

DOSAR

EIC

FERMI

GAC

IRA

EUR-LUX 
Name

John P. Lambert

B. Burgkhardt

E. Piesch

Richard Oswald Robert Wheeler

L. G. Beuchler

G. H. Zeman

D. T. Bartlett

E. A. Ulicny

D. K. Bruening

L. G. Sealock

Joseph R. Stencel

David Katzman

Stephen M. Kim

R. P. Bradley
Affiliation

Kansas State University

Office of Campus Safety

Ward Hall

Manhattan, KS 66506

Kernforschungszentrum Karlsruhe GmbH GFK Postfach 3640, D 7500 Karlsruhe 1

Federal Republic of Germany

R. S. Landauer, Jr., \& Co.

Division of Technical Operations Incorporated

Glenwood Science Park

Glenwood, IL 60425

National Naval Medical Center

Bureau of Medicine and Surgery Dosimetry Center

Radiological Safety Service

Bethesda, MD 20014

National Radiological Protection Board, Harwe 11 Didcot

Oxfordshire OXI1 ORQ

United Kingdom

Notre Dame

Radiation Laboratory

Notre Dame, IN 46556

Omaha Public Power District

1623 Harney

Omaha, NE 68102

Princeton University

Plasma Physics Laboratory

James Forrestal Campus

P. 0. Box 451

Princeton, NJ 08540

Radiation Management Corporation

3508 Markel Street

Philadelphia, PA 19104

Radiation Protection Bureau

Brookfield Road

Ottawa, Ontario KIA $1 \mathrm{Cl}$

Canada
LAND

Identifying

abbreviation

KSU

BUMED

NRPB

ND

OPPD

PPPL

RMC

RPB 
Name

Billy Smith Mike Lantz

R. B. Falk

C. R. Lagerquist

J. R. Pennock

D. J. Thompson

J. St. Germain

John L. Lobde11

Bob Howers

Art Perez

T. K. Uownard

Michael Baumann

John Flynn

G. R: Holeman

\section{Affiliation}

Reynolds Electric and Engineering Company

P. 0. Box 14400

Las Vegas, NV 89114

Rockwell International

Rocky Flats Plant

P. 0. Box 464

Golden, CO 80401

Sandia Laboratories

Albuquerque, NM 87115

Sloan Kettering Memorial Hospital

411 East 67th SLreet

New York, NY 10021

Tennessee Valley Authority

Muscle Shoals, AL 35660

University of California-Davis

Office of Environmental Health and Safety

Davis, CA 95616

University of Utah

Radiological Health Department

100 Orson Spencer Hall

Salt Lakè City, UT 84112

University of Wisconsin-Madison

Safety Department, Room 103

1410 Jnhnson Drive

Madison, WI 53706

Yale University

Health Physics Division

314 Wright Nuclear Structure

Laboratory, West

New Haven, CT 06520
Identifying

abbreviation

REECO

RFP

SLA

SK

TVA

UCD

UTAH

UW

YALE 


\section{THIS PAGE}

WAS INTENTIONALLY

LEFT BLANK 
APPENDIX B 


\section{THIS PAGE}

\section{WAS INTENTIONALLY LEFT BLANK}


PDIS Announcement Letter

OAK RIDGE NATIONAL LABORATORY

OPERATED BY

UNION CARBIDE CORPORATION

NUCLEAR DIVISION

CANION

POST OFFICE BOX $X$

OAK RIDGE, TENNESSEE 37830

The Fifth Personnel Dosimetry Intercomparison Study (PDIS) will be held at the Oak Ridge National Laboratory's Dosimetry Applications Research (DOSAR) facility on March 20, 21, and 22, 1979. The Health Physics Research Reactor (HPRR) will be the source of neutron and gamma radiation for the experiments. Participants' personnel dosimeters will be located on water-filled Bomab phantoms. The dosimeters will be exposed to a range of doses and neutron-to-gamma ratios which could be encountered in personnel monitoring. The attachment to this letter contains details and limitations related to the various exposures.

Participants are expected to mail their dosimeters to the DOSAR facility where the staff will conduct the irradiation experiments. The dosimeters will be returned to the participants for evaluation as soon as possible after exposure. Participants agree to provide the staff with their final dose estimates by July 2, 1979 (102 days after the study) so that the results may be tabulated and distributed in a timely fashion. One of the past shortcomings of the PDIS has been the long time the participants have had to wait for published results. The DOSAR staff is committed to correcting this shortcoming so that these studies will be even more valuable to participants as they test their ability to accurately monitor neutron and gamma dose.

If a dosimeter will be activated to $>.002 \mu \mathrm{Ci} / \mathrm{g}$ when exposed to a fast neutron fluence of $10^{8} \mathrm{n} / \mathrm{cm}^{2}$, the participant must fill out and send us either ERDA form 375 or 391 , as appropriate, in order for us to be able to ship the dosimeters back promptiy. If you wish to participate and do not have such a form, let us know and we will send you some. In filling out the form, be sure to specify each element in the dosimeter and its activity if the activity will exceed $.002 \mu \mathrm{Ci} / \mathrm{g}$. 
Fifth Personnel Dosimetery

Intercomparison Study (PDIS)

There is no fee for participation in the study. Expenses to you will include mailing costs (both ways) and, if your dosimeters are activated in excess of the above stated limit, a small (about $\$ 65$ ) isotope handling fee imposed by the laboratory shipping department. (Please contact us about how such a fee can be paid). If you plan to participate in the study, please let us know by March 5 and send your dosimeters so they will arrive no later than March 15. If you have any questions or suggestions, please write or call us at 615/574-5860 or 5851 (FTS: 624-5860 or 5851).

Sincerely yours.

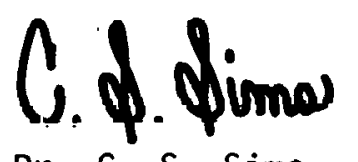

Dr. C. S. Sims

Health and Safety Research Division

CSS : md

Attachment 


\section{ATTACHMENT}

\section{Exposure Information}

There will be six exposures, two different total doses (no single dose will exceed 1.5 rem) for each of three shielding configurations.

\begin{tabular}{cc} 
Exposure number & Shield type \\
\cline { 2 - 2 } 1 & none \\
2 & none \\
3 & $12-\mathrm{cm}$ Lucite \\
4 & $12-\mathrm{cm}$ Lucite \\
5 & $20-\mathrm{cm}$ concrete \\
6 & $20-\mathrm{cm}$ concrete
\end{tabular}

The DOSAR staff will mount a maximum of three dosimeters per participant per exposure. In addition, participants may choose to send a maximum of three background dosimeters. The maximum number (and the number recommended by the staff) of dosimeters allowed each participant is 21 (i.e., $3 \times 6+3$ ). The dosimeters should be labelled as follows:

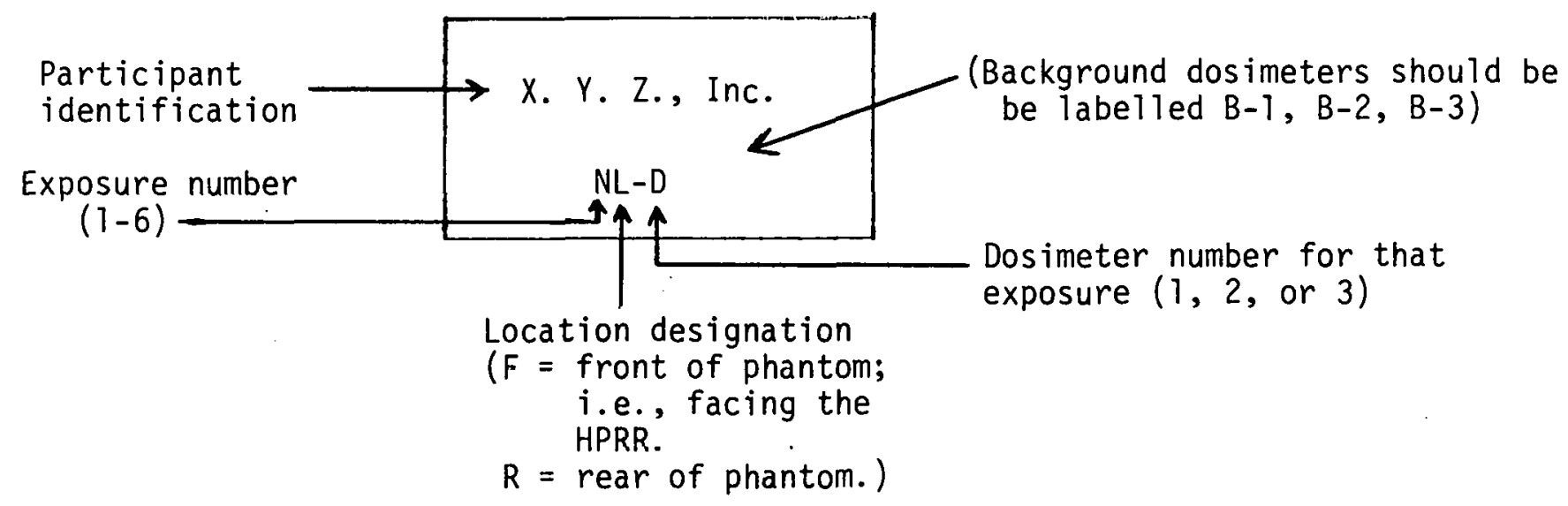

Example:

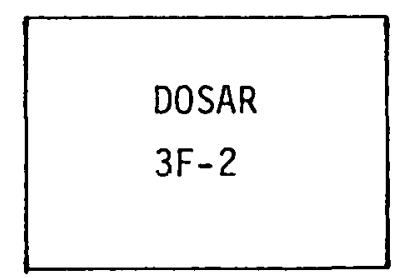

This label identifies the dosimeter as belonging to the DOSAR facility. It is to be mounted on the front of the phantom for exposure no. 3 . It is DOSAR dosimeter no. 2 for that exposure. (If DOSAR exposes 3 dosimeters on the front of phantoms for exposure no. 3 , they will be $3 \mathrm{~F}-1,3 \mathrm{~F}-2$, and $3 F-3)$. 


\section{THIS PAGE}

\section{WAS INTENTIONALLY \\ LEFT BLANK}




\section{APPENDIX C}




\section{THIS PAGE}

WAS INTENTIONALLY LEFT BLANK 
HPRR spectra: Unshielded and through 12-cm Lucite

\begin{tabular}{|c|c|c|c|c|}
\hline \multirow{2}{*}{ Group } & \multirow{2}{*}{$\begin{array}{l}\text { Upper } \\
\text { energy } \\
(\mathrm{eV})\end{array}$} & \multirow{2}{*}{$\begin{array}{c}\text { Mid- } \\
\text { enerqy } \\
(e V)\end{array}$} & \multicolumn{2}{|c|}{$N(E) \Delta E^{a}, n / c^{2}$} \\
\hline & & & No shield & Lucite shield \\
\hline 1 & $1.49 \mathrm{E} 7$ & $1.22 E 7$ & $9.53 E 7$ & $3.31 E 7$ \\
\hline 2 & $1.00 E 7$ & $8.19 \mathrm{E} 6$ & $1.18 \mathrm{Eg}$ & $3.63 \mathrm{E} 8$ \\
\hline 3 & $6.70 \mathrm{E} 6$ & $5.77 \mathrm{E} 6$ & $3.43 \mathrm{Eg}$ & $4.29 \mathrm{E} 8$ \\
\hline 4 & 4. $97 \mathrm{E} 6$ & $3.87 \mathrm{E} 6$ & 1.44ETO & $2.58 \mathrm{Eg}$ \\
\hline 5 & $3.01 E 6$ & 2.12E6 & $3.76 E 10$ & $5.56 \mathrm{E} 9$ \\
\hline 6 & $1.50 \mathrm{E} 6$ & $1.16 \mathrm{E} 6$ & $3.16 \mathrm{EIO}$ & $3.19 \mathrm{Eg}$ \\
\hline 7 & $9.07 E 5$ & $6.08 \mathrm{E} 5$ & $4.61 E 10$ & $3.69 \mathrm{Eg}$ \\
\hline 8 & $4.08 \mathrm{E} 5$ & $2.13 \mathrm{E} 5$ & 3.39E10 & $3.08 \mathrm{E} 9$ \\
\hline 9 & $1.11 \mathrm{E} 5$ & $9.80 \mathrm{E} 4$ & $2.60 E 9$ & $4.18 \mathrm{E} 8$ \\
\hline 10 & $8.65 E 4$ & $7.64 E 4$ & 2.00E9 & $3.81 \mathrm{E} 8$ \\
\hline 11 & $6.74 E 4$ & $5.95 \mathrm{E} 4$ & 1.50E9 & $3.49 \mathrm{E} 8$ \\
\hline 12 & $5.25 \mathrm{E} 4$ & $4.63 \mathrm{E} 4$ & $1.21 \mathrm{Eg}$ & $3.24 \mathrm{E} 8$ \\
\hline 13 & $4.09 \mathrm{E} 4$ & $3.61 \mathrm{E4}$ & $9.71 E 8$ & $3.05 \mathrm{E} 8$ \\
\hline 14 & $3.18 \mathrm{E} 4$ & $2.81 E 4$ & $8.40 E 8$ & $2.98 \mathrm{E} 8$ \\
\hline 15 & $2.48 \mathrm{E} 4$ & $2.19 \mathrm{~F}_{4}$ & $7.35 \mathrm{E} 8$ & 2.76E8 \\
\hline 16 & $1.93 \mathrm{E} 4$ & $1.70 E 4$ & $6.37 E 8$ & $2.66 \mathrm{E} 8$ \\
\hline 17 & $1.50 \mathrm{E} 4$ & $1.03 E 4$ & $1.58 \mathrm{E} 9$ & $7.60 \mathrm{E} 8$ \\
\hline 18 & $7.10 \mathrm{E} 3$ & $4.88 E 3$ & 1.39E9 & $7.23 \mathrm{E} 8$ \\
\hline 19 & $3.35 \mathrm{E} 3$ & $2.03 E 3$ & $1.62 \mathrm{Eg}$ & $9.49 \mathrm{ES}$ \\
\hline 20 & $1.23 \mathrm{E} 3$ & $8.48 E 2$ & $1.04 \mathrm{Eg}$ & $6.97 \mathrm{E} 8$ \\
\hline 21 & $5.83 \mathrm{E} 2$ & $3.54 \mathrm{E} 2$ & $1.24 \mathrm{Eg}$ & $9.21 \mathrm{~EB}$ \\
\hline 22 & $2.14 \mathrm{E} 2$ & $1.47 \mathrm{E} 2$ & $8.45 \mathrm{E} 8$ & $6.91 \mathrm{E} 8$ \\
\hline 23 & $1.01 \mathrm{E2}$ & $6.96 \mathrm{E} 1$ & $7.76 \mathrm{E} 8$ & $6.90 \mathrm{E} 8$ \\
\hline 24 & $4.76 \mathrm{E}]$ & $3.73 \mathrm{E} 1$ & $4.72 \mathrm{E} 8$ & $4.59 E 8$ \\
\hline 25 & 2.90EI & $2.26 \mathrm{E}_{1}$ & $4.54 \mathrm{E} 8$ & $4.60 \mathrm{E} 8$ \\
\hline 26 & $1.76 \mathrm{EI}$ & $1.37 \mathrm{El}$ & $4.34 \mathrm{E} 8$ & $4.61 \mathrm{E} 8$ \\
\hline 27 & $1.07 E 1$ & 7.34 & $6.09 \mathrm{E} 8$ & $6.93 \mathrm{E} 8$ \\
\hline 28 & 5.04 & 3.93 & 3.82E8 & $4.58 \mathrm{E} 8$ \\
\hline 29 & 3.06 & 2.18 & $4.84 \mathrm{E} 8$ & $6.11 \mathrm{E} 8$ \\
\hline 30 & 1.56 & 1.25 & $3.04 \mathrm{E} 8$ & 3.79E8 \\
\hline 31 & 1.00 & $8.06 \mathrm{E}-1$ & $2.81 \mathrm{E} 8$ & $3.41 E 8$ \\
\hline 32 & 0.65 & $5.41 \mathrm{E}-1$ & $2.43 \mathrm{E} 8$ & $2.86 \mathrm{E} 8$ \\
\hline 33 & 0.45 & $2.12 \mathrm{E}-1$ & $1.78 \mathrm{Eg}$ & $2.67 \mathrm{Eg}$ \\
\hline 34 & $\begin{array}{l}0.10 \\
5.0 \mathrm{E}-3\end{array}$ & 2.24E-2 & $3.36 \mathrm{Eg}$ & $1.95 \mathrm{E} 10$ \\
\hline \multirow{2}{*}{\multicolumn{3}{|c|}{$\begin{array}{l}\text { Total fluence at } 3 \mathrm{~m} \text { from } \\
\text { HPRR for } 10^{17} \text { fissions, } \mathrm{n} / \mathrm{cm}^{2}\end{array}$}} & $19.61 \mathrm{E} 10$ & $5.33 \mathrm{E} 10$ \\
\hline & & & & \\
\hline
\end{tabular}
interval.

$a_{\text {This number is the area of the histogram for each energy }}$ 


\section{THIS PAGE}

WAS INTENTIONALLY

LEFT BLANK 


\section{APPENDIX D}


THIS PAGE

WAS INTENTIONALLY

LEFT BLANK 
HPRR spectra: Unshielded and through 20-cm concrete

\begin{tabular}{|c|c|c|c|c|}
\hline \multirow{2}{*}{ Group } & \multirow{2}{*}{$\begin{array}{l}\text { Mid-energy } \\
(\mathrm{eV})\end{array}$} & \multirow{2}{*}{$(\mathrm{eV})$} & \multicolumn{2}{|c|}{$N(E) \Delta E^{a}, n / \mathrm{cm}^{2}$} \\
\hline & & & No shield & Concrete shield \\
\hline 1 & $1.32 \mathrm{E} 7$ & $1.36 \mathrm{E} 7$ & $2.16 \mathrm{Eg}$ & $5.15 E 8$ \\
\hline 2 & $5.62 \mathrm{E} 6$ & $1.63 \mathrm{E} 6$ & $4.08 \mathrm{E} 9$ & $9.60 \mathrm{E} 8$ \\
\hline 3 & $3.90 \mathrm{E} 6$ & $1.80 \mathrm{E} 6$ & $1.43 \mathrm{E} 10$ & 2.36Eg \\
\hline 4 & $2.25 \mathrm{E} 6$ & $1.50 \mathrm{E} 6$ & $3.77 \mathrm{E} 10$ & $9.72 \mathrm{Eg}$ \\
\hline 5 & $1.20 \mathrm{E} 6$ & $6.00 \mathrm{E} 5$ & 3.27E10 & $4.57 \mathrm{Eg}$ \\
\hline 6 & $6.50 \mathrm{E} 5$ & 5.00 E5 & $4.73 \mathrm{E} 70$ & $9.35 \mathrm{Eg}$ \\
\hline 7 & $2.64 \mathrm{E} 5$ & $2.72 \mathrm{E} 5$ & 3.06E10 & $7.54 \mathrm{Eg}$ \\
\hline 8 & $1.07 E 5$ & $4.33 \mathrm{E} 4$ & $4.85 \mathrm{Eg}$ & $2.28 \mathrm{Eg}$ \\
\hline 9 & $7.90 E 4$ & $1.20 \mathrm{E} 4$ & $1.28 \mathrm{Eg}$ & $6.96 \mathrm{E} 8$ \\
\hline 10 & $6.25 \mathrm{E} 4$ & $2.10 \mathrm{E} 4$ & $2.36 \mathrm{Eg}$ & $1.72 \mathrm{E} 9$ \\
\hline 11 & $4.85 \mathrm{E} 4$ & $7.00 \mathrm{E} 3$ & $8.48 E 8$ & $6.84 \mathrm{E} 8$ \\
\hline 12 & $3.75 \mathrm{E} 4$ & $1.50 \mathrm{E} 4$ & $1.81 \mathrm{Eg}$ & $1.80 \mathrm{Eg}$ \\
\hline 13 & $2.75 \mathrm{E} 4$ & $5.00 \mathrm{E} 3$ & $6.87 \mathrm{E} 8$ & $7.80 \mathrm{E} 8$ \\
\hline 14 & $2.10 \mathrm{E}_{4}$ & $8.00 \mathrm{E} 3$ & $1.24 \mathrm{Eg}$ & $1.55 E 9$ \\
\hline 15 & $1.50 \mathrm{E} 4$ & $4.00 \mathrm{E} 3$ & $7.64 \mathrm{E} 8$ & $1.06 \mathrm{Eg}$ \\
\hline 16 & $1.05 E 4$ & $4.97 \mathrm{E} 3$ & $1.21 \mathrm{Eg}$ & $1.86 \mathrm{Eg}$ \\
\hline 17 & $5.52 \mathrm{E} 3$ & $5.03 \mathrm{E} 3$ & $1.94 \mathrm{Eg}$ & $3.47 \mathrm{Fg}$ \\
\hline 18 & $2.08 \mathrm{E} 3$ & $1.85 \mathrm{E} 3$ & $1.76 \mathrm{Eg}$ & $3.60 \mathrm{Eg}$ \\
\hline 19 & $8.50 \mathrm{E} 2$ & 6.00E2 & $1.10 \mathrm{Eg}$ & $2.46 \mathrm{Eg}$ \\
\hline 20 & $3.80 \mathrm{E} 2$ & $3.40 \mathrm{E} 2$ & $1.35 \mathrm{Eg}$ & 3.31Eg \\
\hline 21 & $1.55 \mathrm{E} 2$ & $1.10 \mathrm{E} 2$ & $9.65 \mathrm{~EB}$ & $2.60 \mathrm{Eg}$ \\
\hline 22 & 74.2 & 57.7 & $8.22 \mathrm{E} 8$ & $2.31 \mathrm{Eg}$ \\
\hline 23 & 39.2 & 18.3 & 5.30E8 & $1.57 \mathrm{Eg}$ \\
\hline 24 & 23.5 & 13.0 & $5.97 \mathrm{E} 8$ & $1.84 \mathrm{Eg}$ \\
\hline 25 & 13.5 & 7.00 & $5.23 \mathrm{E} 8$ & $1.67 \mathrm{Eg}$ \\
\hline 26 & 7.50 & 5.00 & $5.96 \mathrm{E} 8$ & $1.95 \mathrm{Eg}$ \\
\hline 27 & 4.03 & 1.95 & $4.42 \mathrm{E} 8$ & $1.50 E 9$ \\
\hline 28 & 2.32 & 1.46 & $6.47 \mathrm{E} 8$ & $2.30 \mathrm{Eg}$ \\
\hline 29 & 1.30 & 0.59 & $4.14 \mathrm{E} 8$ & $1.68 \mathrm{Eg}$ \\
\hline 30 & 0.825 & 0.35 & $3.51 \mathrm{E} 8$ & $1.39 \mathrm{Eg}$ \\
\hline 31 & 0.550 & 0.20 & $3.09 \mathrm{E} 8$ & $1.24 \mathrm{Eg}$ \\
\hline 32 & 0.275 & 0.35 & $1.02 E 9$ & $4.14 \mathrm{Eg}$ \\
\hline 33 & 0.050 & 0.10 & $4.50 \mathrm{Eg}$ & $1.63 \mathrm{E} 10$ \\
\hline \multicolumn{3}{|c|}{$\begin{array}{l}\text { Total fluence at } 3 \mathrm{~m} \text { from } \\
\text { HPRR for } 10^{17} \text { fissions, } \mathrm{n} / \mathrm{cm}^{2}\end{array}$} & $20.18 E 10$ & $10.01 \mathrm{E} 10$ \\
\hline
\end{tabular}
interval.

$a_{\text {This represents the area of the histogram for each energy }}$ 
THIS PAGE

WAS INTENTIONALLY LEFT BLANK 
APPENDIX E 
THIS PAGE

\section{WAS INTENTIONALLY LEFT BLANK}


Post Experiment Letter and Data Report Sheet

\author{
OAK RIDGe National laboratory \\ OPERATED BY \\ UNION CARBIDE CORPORATION \\ NUCLEAR DIVISION \\ CANGON \\ POST OFFICE BOX $X$ \\ OAK RIDGE, TENNESSEE 37830
}

The Fifth Personnel Dosimetry Intercomparison Study was held on March 20, 21, and 22, 1979 at the Oak Ridge National Laboratory's Dosimetry Applications Research (DOSAR) facility. Twenty-nine (29) organizations exposed dosimeters during the study. Your dosimeters were shipped from the laboratory on March 23.

Data related to the Health Physics Research Reactor radiation exposures is in the following table:

\begin{tabular}{ccccc}
$\begin{array}{c}\text { Exposure } \\
\text { Number }\end{array}$ & Shield & $\begin{array}{c}\text { Date of } \\
\text { Exposure }\end{array}$ & $\begin{array}{c}\text { Time of Start } \\
\text { of Exposure, EST }\end{array}$ & $\begin{array}{c}\text { Duration of } \\
\text { Exposure, sec }\end{array}$ \\
\cline { 1 - 1 } 1 & none & $3 / 20 / 79$ & 1031 & 503 \\
2 & none & $3 / 20 / 79$ & 1312 & 537 \\
3 & $12-\mathrm{cm}$ Lucite & $3 / 21 / 79$ & 0923 & 508 \\
4 & $12-\mathrm{cm}$ Lucite & $3 / 21 / 79$ & 1122 & 576 \\
5 & $20-\mathrm{cm}$ concrete & $3 / 21 / 79$ & 1405 & 524 \\
6 & $20-\mathrm{cm}$ concrete & $3 / 22 / 79$ & 0912 & 466
\end{tabular}

In order for the study to be of maximum value to each participant, publication of the results should not be unnecessarily delayed. We look forward to receiving your results on the enclosed Data Report Sheet as soon as possible, but certainly before July 2, 1979. Your participation is appreciated.

\title{
Sincerely,

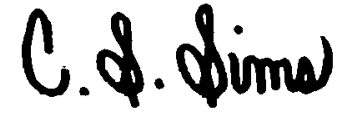

Dr. C. S. Sims

Health \& Safety Research Division

CSS:md

Enclosure 
FIFTH PERSONNEL DOSIMETRY INTERCOMPARISON STUDY

Data Report Sheet

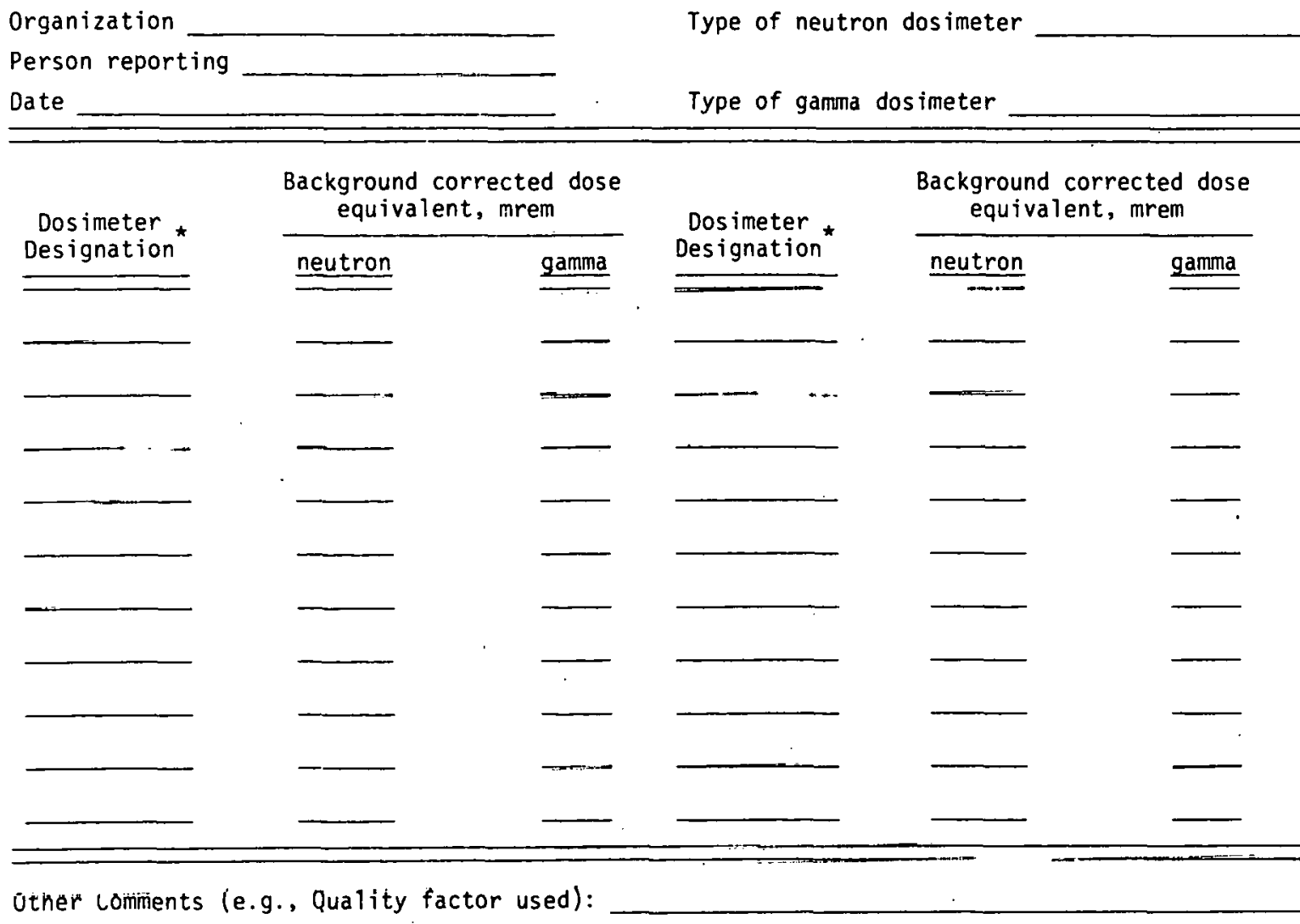

Please return this sheet as soon as possible (before July 2, 1979) to:

C. S. Sims

Oak Ridge National Laboratory

Health \& Safety Research Division

P. 0 . Box $x$, Bildg. 1110

Oak Ridge, TN 37830

* If you followed the requested dosimeter label format, please report IFI, IF2, IR3, etc.

If you did not follow that, please report the number on the dosimeter (e.g., 72-340)

which we have recorded. 
APPENDIX $F$ 
THIS PAGE

WAS INTENTIONALLY

LEFT BLANK 


\section{PARTICIPANT COMMENTS RELATED TO THEIR DOSIMETERS ${ }^{a}$ AND MEASUREMENTS}

Along with the dose results, some groups reported additional data and made comments about their dosimetry. These data and comments are reproduced in this appendix and are valuable as aids to understanding the various dose measurement, calibration, and calculational techniques used by the participants.

$B M I^{b}$ - One of the three background dosimeters yielded a gamma dose of $320 \mathrm{mrem}$. The others were $<10 \mathrm{mrem}$.

CERN - Neutron calibration was done with a plutonium-beryllium source.

GFK - The effective neutron energy based on correlation between albedo response and albedo dosimeter readings was $590 \mathrm{keV}$ for the unshielded cases, $400 \mathrm{keV}$ for the Lucite shielded cases, and 300 keV for the concrete shielded cases. The GFK track dosimeter was calibrated with a ${ }^{252} \mathrm{Cf}$ source.

IRA - Our dosimeter is used for the measurement of beta and gamma radiation. We have not studied its sensitivity to neutrons through the ${ }^{6} i(n, \alpha)^{3} H$ reaction. The doses are interpreted as gamma doses. The background is about $70 \mathrm{mrem}$.

IRD-CS - The detectors were etched electrochemically. The precision was about $\pm 25 \%$. The quality factor was taken from NCRP38.

$a_{\text {Participant furnished descriptions of their dosimeters are in }}$ Table 2 of this report. The dose equivalent unit used by participants in these comments is mrem: 1 mrem $=10^{-5} \mathrm{sv}$.

${ }^{b}$ Identifying acronyms are defined in Appendix $A$. 
LAND - The Neutrak dosimeters were calibrated using the HPRR.

The CR-39 dosimeters were calibrated using an americiumberyllium spectrum and are not corrected for the associated reactor spectrum used in the intercomparison. NRPB - The dosimeters were calibrated with an americiumberyllium source. A fluence to dose equivalent conversion factor of $3.7\left(10^{-8}\right)$ rem- $-\mathrm{cm}^{2}-\mathrm{m}^{-1}$ (ICRP 21) was used for that source.

OPPD - The badges used to monitor the background dose indicated a relatively high background neutron dose. The average neutron background dose of 98 mrem was calculated by assuming the neutrons causing the background dose had the same spectrum as the no shield spectrum. This is the most conservative method for calculating the background neutron dose. If the background neutrons are assumed to have the same spectrum as the Lucite moderated spectrum, the àverage background neutron dose reduces to $31 \mathrm{mrem}$. The Luc1te moderated beam has an average energy of $2.8\left(10^{6}\right) \mathrm{eV}$. If the actual background neutron beam had an average energy which was less than the Lucite moderated beam, the actual dose would be even less than 31 mrem.

REECO - The analytical difficulty of this experiment lies in determining the proper calibration factors. Previous research by Dale E. Hankins on this badge was our only lead to these values. This system's accuracy and precision will be concluded from this experiment, al though there is al ready evidence that the precision is good. This will be proved by the results of the two doses per pulse. * If the system is incorrect by say *It is presumed that REECO means the two steady state runs per shielding configuration. 
$30 \%$ on exposure 3 , then it should also be off by approximately $30 \%$ on exposure 4. The same should hold true for pairs 1-2 and 5-6 if the precision is to be found good. Other initial evidence is the uniformity of the three measurements in each exposure and the consistency of the four TLDs in each badge.

The gamma determinations are quite secondary in importance to this study for us because this dosimeter was not designed for gamma dosimetry. Due to the complications of a neutron exposure to a cadmium badge (i.e., the neutron-gamma reaction), gamma calibration factors for each pulse had to be obtained from previous research by Dale E. Hankins.

As a final note of interest to you, our background badges ( $B$ $1, B-2$, and $B-3$ ) registered a positive neutron dose. Although the spectra involved in this dose are unknown, the measurements indicate a dose of less than $20 \mathrm{mrem}$. The following is a list of our background badge readouts as compared to readouts from badges stored in a lead pig at the Nevada Test Site from anneal to readout. The higher ${ }^{6} \mathrm{Li}$ readouts are apparent in the badges sent to the experiment.

\begin{tabular}{|c|c|c|c|c|c|c|c|c|c|}
\hline$B-$ & & $B-$ & & TLD, & $\begin{array}{l}\text { idout } \\
\text { nc) }\end{array}$ & Ons & 1 & $\begin{array}{l}\text { Ons } \\
\text { cont }\end{array}$ & $\begin{array}{l}e \\
01\end{array}$ \\
\hline$\overline{L i}$ & $\overline{7 \mathrm{Li}}$ & ${ }^{6} \mathrm{Li}$ & $7 / 1$ & ELI & $7 \operatorname{Li}$ & бLi & $7 \mathrm{Li}$ & бLi. & $7 \mathrm{Li}$ \\
\hline $\begin{array}{l}6.084 \\
6.356 \\
6.023 \\
5.793\end{array}$ & $\begin{array}{l}4.145 \\
4.585 \\
4.605 \\
4.492\end{array}$ & $\begin{array}{l}6.293 \\
6.338 \\
6.719 \\
6.715\end{array}$ & $\begin{array}{l}4.846 \\
5.383 \\
6.543 \\
5.705\end{array}$ & $\begin{array}{l}6.305 \\
6.194 \\
6.201 \\
6.203\end{array}$ & $\begin{array}{l}5.428 \\
5.342 \\
5.263 \\
5.199\end{array}$ & $\begin{array}{l}4.182 \\
4.002 \\
4.154 \\
3.868\end{array}$ & $\begin{array}{l}3.838 \\
4.097 \\
4.292 \\
4.103\end{array}$ & $\begin{array}{l}3.569 \\
3.541 \\
3.449 \\
4.221\end{array}$ & $\begin{array}{l}4.054 \\
3.880 \\
4.133\end{array}$ \\
\hline $\begin{array}{l}\text { Averag } \\
6.064\end{array}$ & .457 & 6.516 & 5.619 & 6.226 & 5.308 & 4.052 & 4.083 & 3.695 & 4.122 \\
\hline
\end{tabular}


RPB - Interpretation of the registered neutron exposures was made using a plutonium-beryllium source. No corrections were made for spectral differences as we are interested in determining the degree of overresponse for the dosimeter when exposed to these "softer" spectra.

TVA - A quality factor of 10 was used for the fast neutron component of the dose.

UTAH - The neutron dose is reported in mrad. We have no means of determining the energy of the ncutrons detected and cannot assign a quality factor. The TLD method used is a screening method only and is not suitable for personnel dosimetry applications. 
ORNL/TM-7155

INTERNAL DISTRIBUTION

1-2. Central Research Library

3. Document Reference Section

4-5. Laboratory Records Department

6. Laboratory Records, ORNL R.C.

7. ORNL Patent Office

8. J. A. Auxier

9. S. J. Cotter

10. H. W. Dickson

11. R. B. Gámmage

12. L. W. Gilley

13. E. D. Gupton

14. F. F. Haywood
15. L. B. Holland

16. S. V. Kaye

17. AT King

18. W. T. Mullins

19. G. R. Patterson

20. P. S. Rohwer

21. M. T. Ryan

22. T. L. Rucker

23. C. S. Sims

24. C. M. West

25. D. C. Parzyck

26-40. DOSAR files

\section{EXTERNAL DISTRIBUTION}

41. R. E. Alexander, U.S. Nuclear Regulatory Commission, 5650 Nicholson Lane, Rockville, MD 20555

42. D. T. Bartlett, National Radiological Protection Board, Harwell Didcot, Oxfordshire OX11 ORQ, United Kingdom

43. Michael Baumann, University of Wisconsin-Madison, Safety Department, Room 103, 1410 Johnson Drive, Madison, WI 53706

44. L. G. Beuchier, National Naval Medicai Center, Bureau of Medicine and Surgery Dosimetry Center, Radiological Safety Service, Bethesda, MD 20014

45. W. E. Bleiler, Argonne National Laboratory, 9700 South Cass Avenue, Argonne, IL 60439

46. R. P. Bradley, Radiation Protection Bureau, Brookfield Road, Ottawa, Ontario KTA TCl, Canada

47. D. K. Bruening, Omaha Public Power District, 1623 Harney, Omaha, NE 68102

48. B. Burgkhardt, Kernforschungszentrum Karlsruhe, Postfach 3640 , 7500 Karlsruhe, Federal Republ ic of Germany

49. Rick Cummings, Battelle Pacific Northwest Laboratories, P.0. Box 999, Richland, WA 99352

50. Jan Cusimano, Department of Energy-RESL, Idaho Operations Office, 550 Second Street, Idaho Falls, ID 83401

51. Howard Delafield, Environmental and Medical Sciences Division, AERE, Harwell, Oxfordshire, England OXI1 ORA

52. T. R. Downard, University of Utah, Radiological Health Department, 100 Orson Spencer Ha11, Salt. l.ake City. UT 84112

53. J. Dutrannois, CERN, European Organization for Nuclear Research, $\mathrm{CH} 1211$ Geneve 23, Suisse, Switzerland

54. Great Ehrlich, Room C-210, Radiation Physics Building, National Bureau of Standards, Washington, DC 20234 
55. Roger Falk, Rockwell International, Rocky Flats Plant, P. 0. Box 464, Golden, CO 80401

56. Judith Foulke, U.S. Nuclear Regulatory Commission, 7915 Eastern Avenue, Room 1014, Silver Spring, MD 20555

57. John Flynn, Yale University, Health Physics Division, 314 Wright Nuclear Structure Laboratory, West, New Haven CT 06520

58. Eric Geiger, Eberline Instrument Corporation, P.0. Box 2108, Santa Fe, NM 87501

59. J. St. Germain, Sloan Kettering Memorial Hospital, 411 East 67th Street, New York, NY 10021

60. K. Goebel, CERN, European Organization for Nuclear Research CH 1211 Geneve 23, Suisse, Switzerland

61. Richard Griffith, Lawrence Livermore Laboratory, L383, P.0. Box 808, Livermore, CA 94550

62. D. E. Hankins, Lawrence Livermore Laboratory, L383, P.0. Box 808, Livermore, CA 94550

63. G. R. Holeman, Yale University, Health Physics Division, 314 Wright Nuclear Structure Laboratory, West, New Haven, CT 06520

64. Dave Katzman, Radiation Management Corporation, 3508 Market Street, Science Center Building No. 2, Philadelphia, PA 19104

65. Stephen M. Kim, Radiation Management Corporation, 3508 Market Street, Philadelphia, PA 19104

66. George Kirsch, Battelle Memorial Institute, Columbus Laboratories, 505 King Avenue, Columbus, OH 43201

67. C. R. Lagerquist, Rockwell International, Rocky Flats Plant, P.0. Box 464, Golden, CO 80401

68. John P. Lambert, Kansas State University, Office of Campus Safety, Ward Ha11, Manhattari, K'S 66506

69. Mike Lantz, Reynolds Electric and Engineering Company, P.0. Box 14400, Las Vegas, NV 89114

70. John L. Lobde11. Tennessee Valley Authority, Muscle Shoals, AL 35660

71. Paul Lovendale, Fermilab, Batavia Road, Batavia, IL 60510

72. Wayne Lowder, Environmental Monitoring Laboratory, Department of Energy, 376 Hudson Street, New York, NY 10014

73. A. C. Lucas, The Harshaw Chemical Company, 6801 Cochran Road, Solon, $\mathrm{OH} 44139$

74. S. A. McGuire, Office of Standards Development, U.S. Nuclear Regulatory Commission, Washington, DC 20555

75. M. Oberhofer, Joint Research Center, Ispra Establishment, Euratom C.C.R., 21020 Ispra (Varese), Italy

76. J. R. Ortman, Goodyear Atomic Corporation, P.0, Box 628, Piketon, $\mathrm{OH} 45661$

77. Richard Oswald R. S. Landauer, Jr., and Company, Division of Technical Operations, Incorporated, Glenwood Science Park, Glenwood, IL 60425

78. J. R. Pennock, Rockwell International, Rocky Flats Plant, P.0. Box 464, Golden, CO 80401

79. Art.Perez, University of California-Davis, Office of Environmental Health and Safety, Davis, CA 95616

80. E. Piesch, Kernforschungszentrum Karlsruhe GmbH, Postface 3640 , D 7500 Karlsruhe 1, Federal Republic of Germany 
81. Phillip Plato, School of Public Health, University of Michigan, Ann Arbor, MI 84106

82. Bob Powers, Tennessee Valley Authority, Muscle Shoals, AL 35660

83. W. M. Quam, EG\&G, 130 Robin Hill Road, Goleta, GA 93017

84. Robert B. Schwartz, U.S. Department of Commerce, National Bureau of Standards, RADP B119, Washington, DC 20234

85. L. G. Sealock, Omaha Public Power District, 1623 Harney, Omaha, NE 68102

86. Billy Short, Goodyear. Atomic Corporation, P.0. Box 628, Piketon, $\mathrm{OH} 45661$

87. Billy Smith, Reynolds Electric and Engineering Company, P.0. Box 14400, Las Vegas, NV 89114

88. Frantisek Spurney, Czechoslovak Academy of Sciences, Institute of Radiation Dosimetry, Na Truhlarce 39/2a, 18086 Praha 8, Czechoslovakia

89. Joseph R. Stence1, Princeton University, Plasma Physics Laboratory, James Forrestal Campus, P.0. Box 451, Princeton, NJ 08540

90. Rose Marie Tauche, Eberline Instrument Corporation, P.0. Box 2108, Santa Fe, NM 87501

91. D. J. Thompson, Sandia Laboratories, A1buquerque, NM 87115

92. E. A. Ulicny, Notre Dame University, Radiation Laboratory, Notre Dame, IN 46556

93. Ed Vallario, U.S. Department of Energy, Division of Operational and Environmental Safety, Mail Stop E201, Washington, DC 20545

94. J. F. Valley, Institut de Radiophysique. Appliquee, Centre Universitaire, 1015 Lausanne, Switzerland

95. B. Waldeskog, IAEA, Dosimetry Section, Division of Life Sciences, Karntner Ring 11, P.0. Box 590, A-1011 Vienna, Austria

96. Robert V. Wheeler, R. S. Landauer, Jr., and Company, Division of Technical Operations, Incorporated, Glenwood Science Park, GTenwood, IL 60425

97. R. W. Wood, Division of Pollutant Characterization and Safety Research, Department of Energy, Washington, DC 20545

98. C. N. Wright, Savannah River Laboratory, Aiken, South Carolina 29802

99. G. H. Zeman, National Naval Medical Center, Bureau of Medicine and Suryery Dusimelry Center, Radiological Safety Service, Bethesda, MD 20014

100. Office of Assistant Manager, Energy Research and Development, Department of Energy, Oak Ridge Operations Office, Oak Ridge, TN 37830

101-127. Technical Information Center, Department of Energy, Oak Ridge, TN 37830 